Published in final edited form as:

Clin Hemorheol Microcirc. 2018 ; 68(2-3): 263-299. doi:10.3233/CH-189012.

\title{
Inflammation in Sickle Cell Disease
}

\author{
Nicola Conran ${ }^{1}$ and John D. Belcher ${ }^{2}$ \\ ${ }^{1}$ Hematology Center, University of Campinas - UNICAMP, Cidade Universitária, Campinas-SP, \\ Brazil. \\ 2Division of Hematology, Oncology and Transplantation, Vascular Biology Center, Department of \\ Medicine, University of Minnesota, Minneapolis, Minnesota, USA
}

\begin{abstract}
The primary $\beta$-globin gene mutation that causes sickle cell disease (SCD) has significant pathophysiological consequences that result in hemolytic events and the induction of the inflammatory processes that ultimately lead to vaso-occlusion. In addition to their role in the initiation of the acute painful vaso-occlusive episodes that are characteristic of SCD, inflammatory processes are also key components of many of the complications of the disease including autosplenectomy, acute chest syndrome, pulmonary hypertension, leg ulcers, nephropathy and stroke. We, herein, discuss the events that trigger inflammation in the disease, as well as the mechanisms, inflammatory molecules and cells that propagate these inflammatory processes. Given the central role that inflammation plays in SCD pathophysiology, many of the therapeutic approaches currently under pre-clinical and clinical development for the treatment of SCD endeavor to counter aspects or specific molecules of these inflammatory processes and it is possible that, in the future, we will see anti-inflammatory drugs being used either together with, or in place of, hydroxyurea in those SCD patients for whom hematopoietic stem cell transplants and evolving gene therapies are not a viable option.
\end{abstract}

\section{Keywords}

Cytokine; Endothelium; Hemolysis; Hydroxyurea; Vaso-occlusion

\section{Chronic inflammatory mechanisms in sickle cell disease}

Sickle cell disease (SCD) is caused by a mutation in the $\beta$-globin gene, resulting in the production of hemoglobin $\mathrm{S}(\mathrm{HbS})$ [1], which polymerizes upon deoxygenation of the red blood cell (RBC). This primary pathophysiological alteration has countless consequences, including the production of inflammatory molecules and responses that ultimately lead to vaso-occlusion of microvessels, the principal manifestation of SCD. In addition to driving

\footnotetext{
Address correspondence to: Nicola Conran: Hemocentro, Rua Carlos Chagas 480, Cidade Universitaria, Barao Geraldo. Campinas 13083-878 SP. Tel: +55 193521 8533. conran@unicamp.br; John D. Belcher: Vascular Biology Center, Division of Hematology, Oncology and Transplantation, Department of Medicine, University of Minnesota, Minneapolis, MN. Tel: + 1 612-624-2611, belcher@umn.edu.

9. Disclosures of conflicts of interest

Nicola Conran receives research funding from Bayer AG. Dr. Belcher receives research funding from CSL Behring.
} 
the vaso-occlusive processes that culminate in the acute painful episodes that are the major cause of hospitalization in SCD patients, inflammatory responses are also key components of numerous complications of the disease including autosplenectomy, acute chest syndrome, pulmonary hypertension, leg ulcers, nephropathy and stroke [2-8]. While it is difficult to identify the exact events that trigger the chronic inflammatory state that defines SCD, we herein present some of the pathophysiological mechanisms that may contribute to and drive inflammation in SCD.

\subsection{Sources of inflammation in sickle cell disease}

Red cell alterations- $\mathrm{HbS}$, and its polymerization under deoxygenated conditions, causes RBCs to adopt their characteristic sickled shape, predisposing the cells to a number of intracellular and membrane alterations. These cellular changes alter the RBC redox balance, impair the cells' deformability, make them more adhesive, and leave them susceptible to microparticle release, as well as complement and coagulation system activation, all of which can contribute to inflammatory processes in SCD [9].

Red cell dehydration is a major factor in erythrocyte sickling; $\mathrm{K} / \mathrm{Cl}$ cotransport activity is augmented in sickle RBCs $[10,11]$ and repeated RBC sickling can increase intracellular $\mathrm{Ca}^{2+}$ concentrations [12], resulting in the activation of the erythrocyte $\mathrm{Ca}^{2+}$-dependent $\mathrm{K}^{+}$ Gardos channels [13]. Ensuing intracellular $\mathrm{K}^{+}$and water losses result in the generation of dense dehydrated RBCs, whose numbers have been associated with increased RBC sickling and the incidence of complications of the disease [14-16]. Continuous oxygenation and deoxygenation cycles can culminate in the generation of reactive oxygen species (ROS) in the RBC due to the autooxidation of oxyhemoglobin to methemoglobin and the generation of superoxide anion and hydrogen peroxide. In the case of sickle RBC, this ROS production is aggravated by the instability of $\mathrm{HbS}[17,18]$, coupled with the oxidative effects of free iron, hemoglobin and heme deposits on the cell membrane [15, 19]. The consequent oxidation of RBC membrane proteins may exacerbate the abnormal rheological properties of sickle RBC [20], further impairing the deformability of these cells [21], and may even be a contributing factor to the adhesivity of the sickle RBC [22]. A significant part of ROS production in sickle cells is mediated enzymatically by NADPH oxidase, which is regulated by protein kinase $\mathrm{C}$, Rac GTPase, and intracellular $\mathrm{Ca}^{2+}$ signaling within the sickle $\mathrm{RBC}$ [23]. Plasma from patients with SCD and isolated cytokines, such as transforming growth factor (TGF)- $\beta 1$ and endothelin-1, enhance RBC NADPH oxidase activity and increase ROS generation.

Repeated $\mathrm{HbS}$ polymerizations, together with $\mathrm{RBC}$ dehydration and membrane oxidative injury, result in alterations to the cytoskeleton and membrane components that can leave RBCs irreversibly sickled $[24,25]$. These irreversibly sickled RBCs retain their sickled shape irrespective of whether they carry polymerized HbS or not, and they tend to be dense with low concentrations of fetal hemoglobin $(\mathrm{HbF})$, decreased deformability, increased osmotic fragility and a short survival $[25,26]$. Irreversibly sickled cells probably contribute to the inflammatory state in SCD by participating in hemolytic and occlusive mechanisms in blood vessels [9, 27, 28]. Dehydrated and dense sickle RBCs also externalize negativelycharged phosphatidylserine (PS) on their plasma membrane that, besides contributing to 
sickle RBC adhesive properties [29-31], may activate the coagulation cascade by promoting the generation of thrombin $[32,33]$, though more recent data have suggested that whole blood thrombin generation in SCD may arise from a cellular component rather than PS exposure [34]. Thrombin generation and activation of the coagulation system will be covered in a further subsection of this review.

The contribution of sickle cell adhesiveness to endothelial activation and vaso-occlusive mechanisms has long been recognized $[35,36]$. While normal RBCs present negligible adhesivity, sickle RBCs are much more adhesive due to the expression of multiple adhesion molecules on their cell surface. Sickle RBCs express a $4 \beta 1$, Lu/BCAM, LFA-3 and ICAM-4 [37-39], in addition to PS, on the plasma membrane, allowing the cells to adhere to and bind extracellular matrix proteins and counter receptors on the endothelium. Additionally, sickle RBCs also interact with activated neutrophils and platelets, forming heterocellular aggregates that can adhere to the vessel walls, resulting in the obstruction of microcirculatory flow [40-43].

In addition to membrane alterations, sickle RBCs produce significant quantities of microparticles (MPs) [44], usually observed as spheroid vesicles of 100-300 nm in size that present PS and phosphatidylethanolamine on their membrane surface [45]. Red cell microparticles are generated during reticulocytosis, a process that is exacerbated in SCD [46], and as a result of repeated sickling/unsickling. Continuous $\mathrm{HbS}$ polymerization causes the formation of long spicules, due to alterations in the spectrin-actin meshwork, which can uncouple the lipid bilayer from the cytoskeleton [44, 47, 48], allowing the subsequent release of microvesicles. Additionally, elevated intracellular calcium can activate calpain-1 and other proteases that may destabilize the membrane and allow microparticle release [49]. Other triggers of erythrocyte MP shedding in SCD may include increased thrombospondin-1 [50], RBC membrane oxidation and increased acid sphingomyelinase activity [47, 51, 52].

Red cell MP may be an important source of inflammation in SCD, as they carry large quantities of hemoglobin, heme and iron, potentially making a significant contribution to the quantity of inflammatory hemoglobin products in the SCD circulation. Sickle red cell MP can induce the production of IL-6, TNFa and IL-1 $\beta$ in monocytes [52] and more recent evidence suggests a role for red cell MP in transferring heme to endothelial cells in SCD, causing vascular injury and potentially triggering vaso-occlusive events [53]. The role of MPs in SCD are further discussed in detail in this special SCD issue in Clin Hemorheol Microcirc (see the review of Romana et al.).

Hemolysis and hemoglobin products-Hemolysis is a primary inflammatory trigger in SCD. The alterations in sickle RBCs described above leave these cells more rigid and less deformable and therefore more susceptible to rupture in the circulation. The lifespan of sickle RBCs may be as short as 7-14 days, as compared with the lifespan of approximately 120 days for normal RBC $[1,54]$. The premature destruction of up to $10 \%$ of the total number of RBCs may occur every $24 \mathrm{~h}$ in SCD, with approximately $30 \%$ of total hemolysis occurring intravascularly $[54,55]$ and plasma cell-free heme concentrations of $25 \mu \mathrm{M}$, or more, being reported in steady-state SCD individuals [56]. 
Upon the lysis of RBCs, liberation of cell-free hemoglobin into the circulation occurs. If not sequestered immediately by plasma hemoglobin-binding proteins, such as haptoglobin [57], this cell-free hemoglobin elicits the immediate consumption of nitric oxide (NO), a gaseous signaling molecule that is constitutively produced by endothelial nitric oxide synthase (NOS) [56]. In addition to its vasodilating properties, endothelial-derived NO [58] has significant anti-inflammatory effects, reducing leukocyte activation and leukocyteendothelial interactions, and the emigration of leukocytes from the blood vessels to tissue [59-62]; indeed the installation of vascular hemolysis in mice induces an immediate systemic and vascular inflammatory response, in which NO depletion apparently triggers instantaneous and extensive leukocyte recruitment in the microcirculation [63]. NO also modulates the production of endothelin-converting enzyme-1 [64] and arrests vascular smooth muscle cell proliferation, and is therefore important for preventing vascular remodeling, a mechanism that is central to pulmonary hypertension [65, 66]. NO also significantly inhibits platelet aggregation and the release of pro-inflammatory cytokines and tissue factor from leukocytes and endothelial cells [61, 62, 67-69]. In contrast, in the presence of superoxide, NO forms the highly reactive peroxynitrite, which can oxide lipids, proteins and lipoproteins and promote cellular apoptosis and necrosis [70-72].

Following the reaction of oxyhemoglobin with $\mathrm{NO}$ in the blood vessel, $\mathrm{Hb}-\mathrm{Fe}^{3+}$ is formed, which readily releases heme [73], a highly inflammatory, hydrophobic, iron-containing molecule that can activate the innate immune pattern recognition receptor, toll-like receptor (TLR) 4 on monocyte/macrophages and endothelial cells [74, 75]. Heme and the TLR4 cognate ligand, lipopolysaccharide (LPS), can also activate TLR4 signaling on other cell types such as T-cells, platelets and mast cells [76-79]. Heme activation of TLR4 on lung endothelium can trigger acute chest syndrome in SCD mice [80], tissue factor expression on monocytes [81], and neutrophil NET formation [82, 83]. Heme derived from sickle RBCs can activate TLR4 independently of LPS, leading to oxidant production, inflammation, and vaso-occlusion [74]. Heme-induced TLR4 signaling requires all of the proximal components of classical TLR4 signaling, including TLR4, CD14, MD-2, and MyD88 ([75] and unpublished data). Heme-induced TNF-a secretion occurs independently of the LPS binding site on MD-2/TLR4 and is antagonized by protoporphyrin IX. The inflammatory components of heme-mediated TLR4 signaling include NF- $\mathrm{kB}$ activation, inflammasome assembly, cytokine production, adhesion molecule expression, and rapid (within minutes) mobilization of Weibel-Palade bodies (WPB) to endothelial cell surfaces, which can release a large number of pro-inflammatory and hemostatic proteins. Blockade of P-selectin or von Willebrand Factor (vWF) with functional blocking IgG significantly inhibits heme/TLR4induced vaso-occlusion. Heme-mediated TLR4 activation can also be blocked by the plasma high-affinity heme-binding protein hemopexin, which is depleted in SCD [74, 80, 84, 85].

In addition to heme, RBCs contain numerous other molecules with inflammatory potential, called damage-associated molecular patterns (DAMPs); thus, in addition to the release of hemoglobin and, consequently heme, hemolysis is also accompanied by the release of a number of DAMPs, some of which are listed in Table 1. One such red cell DAMP is adenosine 5' triphosphate (ATP) [86], which in addition to acting as a universal energy source, also has vasoactive properties [87]. Extracellular ATP acts as a signaling molecule via the activation of purinergic $\mathrm{P} 2$ receptors [88], where binding of ATP to the $\mathrm{P} 2 \mathrm{X}_{7}$ 
receptor is known to lead to $\mathrm{K}^{+}$efflux via ATP-gated cation channel opening and trigger assembly of the inflammasome platform, with subsequent IL-1 $\beta$ and IL-18 processing, in certain inflammatory cells [89]. Extracellular ATP can also be rapidly converted to adenosine by ectonucleotidases; when in the extracellular environment, the adenosine purine molecule can exert both anti-inflammatory and pro-inflammatory effects, depending on the receptor with which it interacts. As such, while the interaction of adenosine with the Adora2a adenosine receptor selectively inhibits the iNKT cells, adenosine signaling through the Adora2b adenosine receptor on the RBC membrane appears to induce erythrocyte sickling in SCD [90, 91].

Vaso-occlusive processes and ischemia-reperfusion injury-Vaso-occlusive processes occurring primarily in the microcirculation reduce tissue oxygenation and can culminate in tissue damage and ischemia-reperfusion physiology, which in themselves are highly inflammatory mechanisms. Vaso-occlusion comprises a multi-step and multicomponent process consisting of the initiation, propagation and resolution of vascular obstruction [92], in which numerous cell types and molecular interactions play roles. In vitro techniques and in vivo models have suggested that vaso-occlusion is initiated by the adhesion of RBCs [35,36] and activated leukocytes (which then mediate the secondary adhesion of red cells and platelets) [93, 94] to the endothelium, with the positing of "erythrocentric" and "leukocentric" theories for the precipitation of vaso-occlusion [1] that are not necessarily mutually exclusive. More recent data have also suggested a major role for platelets in vaso-occlusive processes, the adhesion of platelets to endothelial cells leads to their activation and expression of endothelial ICAM-1 and E-selectin and IL-8 secretion via an NFkB-dependent pathway [95], probably due to the release of potent platelet-derived inflammatory mediators such as IL-1 $\beta$, CD40 ligand, TNFSF14 (tumor necrosis factor superfamily member 14; LIGHT) and IL-6 [95-98]. Furthermore, neutrophil-platelet microemboli reportedly trigger lung arteriole vaso-occlusion [40], and it is possible that the adhesion of platelets to damaged endothelium may in fact precede and mediate the adhesion of larger neutrophils and red cells to the vessel wall under some circumstances (Chweih et al, unpublished observations).

Vaso-occlusive processes in SCD cause ischemia-reperfusion injury, defined as the tissue damage that occurs as the result of the interruption of the blood supply causing hypoxia, followed by resolution and consequent reperfusion of the tissue [99]. Cells undergoing cell death mechanisms present cytosolic calcium accumulation, mitochondrial dysfunction and cell swelling $[5,99]$ and release major inflammatory DAMPs, such as ATP, heme, highmobility group box 1 (HMGB1) and heat shock proteins (Table 1), which are reportedly increased in SCD [100, 101]. These DAMPs can promote multiple inflammatory pathways, including NET formation and inflammasome assembly, as will be later described $[89,102]$. When blood flow is restored following disruption of vaso-occlusion, the tissue is then reperfused and the damaged tissues are reoxygenated, paradoxically causing further damage, due to the production of ROS and calcium overload [99]. A major effect of ischemiareperfusion injury may be the activation of iNKT cells, which can induce pulmonary inflammation by triggering IFN- $\gamma$ and INF- $\gamma$-inducible chemokines [103]. 
Infections-Individuals with SCD, particularly children, are very susceptible to bacterial infections due to functional asplenia [104]. The use of penicillin prophylaxis and vaccines, in most children with SCD, has drastically reduced the incidence of severe infections in these patients [105], but nevertheless it is probable that bacterial infections are important triggers of inflammatory responses in the SCD population due to further neutrophil activation and the release of pathogen-associated molecular patterns (PAMPs) that can prime inflammatory cells, aggravate inflammatory processes and trigger innate immunity pathways $[106,107]$.

Histamine-Fasting plasma histamine is elevated in steady state SCD and further augmented during painful vaso-occlusive episodes [108]. It is probable that the major source of plasma histamine in SCD derives from mast cell activation and consequent degranulation, although small amounts of histamine may also be released from intracellular stores during platelet activation $[109,110]$. Mast cell activation has been demonstrated in SCD and contributes to sickle pain pathobiology [111], furthermore, morphine administration (often used during painful vaso-occlusive episodes) may exacerbate cutaneous mast cell degranulation [112], with systemic morphine exposure being suggested to increase the risk for acute chest syndrome in SCD [113]. Histamine, in addition to its roles in vasoregulation, smooth muscle contraction, neurotransmission, and vascular permeability [114], induces $\mathrm{vWF}$ release and thrombospondin-1 and P-selectin exposure on endothelial cells [30, 115, 116], in turn mediating the adhesion of RBCs $[30,117,118]$. Histamine may also elevate circulating leukocyte numbers [119], promote inflammatory angiogenesis [120] and modulate invariant natural killer T cell activation [121, 122].

Oxidative stress-Oxidative stress and inflammation are intrinsic to SCD and inextricably linked to its pathophysiology [23, 96, 123-161]. SCD patients have an imbalance between the production of oxidants and antioxidant capacity, which is a critical factor in endothelial cell dysfunction, inflammation, vaso-occlusion, and organ pathology [162-172]. There are multiple potential sources of oxidants in SCD, including accelerated hemoglobin S (HbS) autoxidation [173], released heme/iron catalyzed Fenton reactions [174], increased expression and activity of various isoforms of NADPH oxidase (NOX) [23, 135, 175, 176], xanthine oxidase [177], cytochrome P450, cyclo-oxygenase [178], mitochondria [179], and uncoupled NOS [180]. Although anti-oxidants act to scavenge ROS produced by these enzymes, their effectiveness has been limited in clinical trials likely because of their non-specificity and the important role oxidative stress plays in the induction of countervailing cytoprotective pathways such as the Nrf2/HO-1 axis. Nevertheless, the US FDA's recent approval of the use of supplementation with L-glutamine in SCD (see Section 6), highlights the fact that anti-oxidant approaches may be a useful adjuvant therapy in SCD, and targeting of oxidant production by specific enzyme systems has the potential to target the formation of oxidants that contribute directly to SCD pathophysiology.

Thrombin generation and activation of complement-SCD is a hypercoagulable state with an increased incidence of prothromboembolic events. Whole blood thrombin generation is significantly elevated in whole blood, but reduced in plasma [34] and this prothrombotic state, involving the activation of platelets and the coagulation system, may play a 
role in some of the complications of the disease, including ischemic stroke and venous thromboembolism (VTE) [181]. Abnormal PS exposure on the sickle RBC surface and circulating erythrocyte-derived microparticles have been suggested to induce excessive thrombin generation in SCD [33]. Evidence suggests that activation of the coagulation system and thrombin generation occur in SCD [182-185], as well as increased tissue factor expression [146, 186-189].

In 1967, Francis and Womack first reported abnormal complement activity in SCD [190]. This was revisited in 1973 by Johnston et al. who reported activation of the alternative pathway (AP) in the disease [191]. The AP can be constitutively activated by spontaneous modification of C3 yielding iC3 (tick-over mechanism), which can bind factor B [192]. The complex can then bind to activating surfaces, with amplification of $\mathrm{C} 3$ convertase, generation of C5 convertase, and finally C5 cleavage. In addition, thrombin can bypass classical and AP complement activation and directly cleave C3 and C5 into biologically active fragments $[193,194]$. Activation of the AP and thrombin pathways is accelerated on PS-rich membrane surfaces. Importantly, C5a can activate all of the cells involved in vasoocclusion (leukocytes, platelets, and endothelial cells), initiate P-selectin expression, elicit the release of pain mediators (histamine, tryptase and substance P) from mast cells and enhance vascular permeability.

In 1994, Chudwin et al. reported that SS-RBCs activated complement to a greater extent than did RBCs from controls [195]. They also reported that this activation was via the AP and not the classical pathway (CP). In 1995, Mold et al. demonstrated that AP activation is initiated by membrane phospholipid changes that occur in SS-RBC [196]. The alternative complement pathway is abnormally activated in SCD [191, 197] and is amplified by PS on the outer leaflet of SS-RBCs and MPs [194, 195, 198, 199]. PS on the surface of SS-RBCs and activated platelets accelerates the assembly of prothrombinase complexes, leading to thrombin generation, which can generate biologically active $\mathrm{C} 3 / \mathrm{C} 5$ fragments, including the anaphylatoxins C3a/C5a [193, 200]. C3b opsonizes SS-RBC and C5b initiates the formation of membrane attack complexes on SS-RBC that respectively increase their susceptibility to extravascular clearance and intravascular lysis [201, 202]. Arumugam et al demonstrated that genetically reducing prothrombin levels limits inflammation, endothelial cell activation, and end-organ damage in SCD mice [154]. Sparkenbaugh et al showed that factor Xa (FXa) and thrombin contribute to inflammation in SCD mice, and inhibitors of FXa (rivaroxaban) and thrombin (dabigatran) reduced this inflammation [150].

\subsection{Propagation of Chronic Inflammation in SCD}

Pro-inflammatory Mediator Production-The activation of the inflammatory cells and their signaling pathways leads to the production and secretion of numerous molecules that propagate the inflammatory state in SCD, including cytokines and chemokines, growth factors, eicosanoids and peptides that can further activate other cells. Numerous type I cytokines, produced from multiple cell types, are elevated in steady-state SCD. A major leukocyte-derived cytokine is tumor necrosis factor (TNF)-a; circulating levels of this molecule are consistently reported as elevated in SCD [142, 203-205] and TNF-a is even frequently used to trigger vaso-occlusive processes in sickle mice models [93, 206]. This 
cytokine is suggested to be generated as an early consequence of ischemia-reperfusion [207] and has potent effects on both leukocytes and endothelial cells. In neutrophils, TNF-a stimulates the surface expression of $\beta-2$ integrins [208], in turn augmenting their adhesion to the blood vessel wall [208] and interactions with other cells via NF- $\kappa$ B and MAPK signaling [209]. Furthermore, TNF-a degrades the endothelial glycocalyx (shown to be reduced in SCD patients) [210, 211], alters endothelium-derived NO bioavailability [212] and upregulates adhesion molecule expression on the endothelium [213], with a monocytedependent TNF-endothelial activation axis being recently described in sickle mice [207].

Interleukin (IL)-1a elevation is reported in SCD and represents a primary inflammatory trigger that induces leukocyte recruitment, endothelial cell activation and the production of other inflammatory mediators [214, 215]. Increased IL-6 in SCD [203, 205, 216, 217] may play a role in acute phase protein synthesis, although this cytokine may also have beneficial effects due to its ability to inhibit TNF- $a$ activity and up-regulate anti-inflammatory IL-10 [218]. The IL-17 cytokine is also elevated in SCD, probably reflecting increased lymphocyte activity and may stimulate the production of chemokines and cytokines involved in neutrophil recruitment to the blood vessel wall [203]. Plasma interferon (IFN)- $\gamma$, a type-2 interferon produced by multiple cell types, is apparently augmented in steady-state SCD and could modulate macrophage function and increase T helper cell expansion [216]. Plateletderived cytokines, such as CD40L and TNSF14, are also elevated in SCD and probably participate in leukocyte and endothelial activation, with evidence for the association of increased levels of these cytokines with acute chest syndrome and elevated tricuspid regurgitant velocity, respectively [96, 97, 219]. Elevated circulating levels of both IL-1 $\beta$ and IL-18 have been observed [205, 220, 221] in SCD and most likely reflect inflammasome formation in inflammatory cells; the IL- $1 \beta$ cytokine may in turn go on to stimulate leukocyte and endothelial cell activation, while IL-18 could be important for stimulating vascular smooth muscle cell proliferation and migration as well as the productions of IFN- $\gamma$, IL-2 and IL-12.

Chemokine upregulation in SCD may facilitate the recruitment of leukocytes, such as neutrophils, eosinophils and monocytes, to blood vessel walls. Chemokines reported to be augmented in SCD include IL-8 (CXCL8), monocyte chemoattractant protein (MCP)-1 (CCL2), RANTES (CCL5), platelet factor (PF) 4 (CXCL4), macrophage inflammatory protein (MIP)-1a, Eotaxin-1 (CCL11) and fractalkine [203, 205, 222-224]. Augmented growth factors in SCD stimulate leukocyte proliferation and differentiation and may regulate some of the angiogenic processes that contribute to some SCD manifestations. Such growth factors include granulocyte macrophage-colony stimulating factor (GM-CSF), macrophageCSF (M-CSF), TGF- $\beta$, and pro-angiogenic molecules [143, 203, 205, 223, 225-230]. Other inflammatory mediators that are upregulated in SCD include substance $\mathrm{P}$, and the acute phase proteins, C-reactive protein and pentraxin-3 [231-233].

The severity and symptoms of sickle cell anemia (SCA) and the other SCD genotypes are surprisingly variable [234], and genetic modulation of the production of cytokines, other inflammatory molecules, and their receptors may constitute one of the mechanisms that contribute to this variation. Polymorphisms in the genes encoding IFN $\gamma$ and TNF-a have been shown to present associations with infectious complications and stroke [235-237], 
while several genes in the TGF-beta/BMP signaling pathway have been associated with the incidence of leg ulcers [238], and the IL1A rs1800587 SNP may influence chronic pain in SCD [239].

\section{Inflammatory Cell Activation}

Endothelial cell activation: Endothelial cell activation plays a key role in the vasoocclusive process. Intact, non-activated endothelium generally averts the adhesion of inflammatory cells to the vessel wall via mechanisms such as NO generation and prostacyclin release [58]. Endothelial dysfunction occurs as a consequence of endotheliumderived NO depletion by cell-free hemoglobin [56, 240], endothelial NOS uncoupling and consumption of L-arginine (the substrate for NOS) by arginase released during hemolysis [241]. The endothelium is further activated by interactions/adhesion of sickle RBCs and leukocytes with the vessel wall [242-244]. Cell-free heme also induces microvascular endothelial barrier dysfunction in the lung by inducing necroptic death [245].

Once activated, the endothelium produces and releases a number of potent inflammatory molecules, including IL-1 $\beta$, IL-8, IL-6, IL-1a, GM-CSF, plasminogen activator inhibitor (PAI)-1, MCP-1 and RANTES [95, 216, 217, 246-249] that contribute to the inflammatory milieu in SCD. Activated endothelium also expresses adhesion molecules such as VCAM-1, ICAM-1, E-selectin and P-selectin [250-253], which are important for red cell, leukocyte and platelet tethering and adhesion. More recently, a role for endothelin-B receptor-mediated signaling in leukocyte adhesion to the endothelium has been shown in SCD [254].

SCD appears to be associated with an imbalance in angiogenic processes, which govern the formation of new capillaries from preexisting vessels and are essential for the repair processes [255] that are necessary after tissue damage. The angiogenic process involves the interactions of several cell types for capillary formation [256], and endothelial cell proliferation and invasion in response to angiogenic mediators and alterations in oxygen tension are crucial to these mechanisms [257, 258]. SCD patients, display a number of manifestations that are suggestive of alterations in the angiogenic processes, such as proliferative retinopathy, osteonecrosis and pulmonary hypertension and moyamoya syndrome amongst others [259-266], where retinopathy and osteonecrosis are often even more frequent in HbSC disease (generally viewed as a less severe disease than homozygous HbS disease) [267, 268]. Numerous angiogenic mediators are elevated in SCD, including vascular endothelial growth factor (VEGF), VEGF D, placental growth factor (PIGF), angiopoietin-1 (Ang1), angiopoietin-2 (Ang2), basic fibroblast growth factor [bFGF] and erythropoietin (EPO) [143, 226-228, 269, 270], furthermore, plasma from SCD individuals induces endothelial cell proliferation and capillary formation in vitro [270], highlighting the important role that endothelial cells play in these mechanisms.

Leukocyte activation: Leukocytes are key players in the inflammatory processes that trigger vaso-occlusion and other complications of SCD, participating in the generation of inflammatory molecules as well as physically contributing to the vaso-occlusive process. SCD is often associated with leukocytosis and a clue to the prominent role of these inflammatory cells to SCD pathophysiology was provided some time ago by the 
demonstration that increased leuckocyte counts are associated with increased mortality, acute chest syndrome and stroke in the disease [271]. Intravital microscopy techniques in murine models of SCD later showed that, under certain circumstances, the recruitment and adhesion of leukocytes, particularly neutrophils, to the microvenule walls may be the trigger for the onset of vaso-occlusive processes. In vitro and in vivo techniques further indicate that, following their recruitment to the vessel walls of the SCD microcirculation, $\beta 2$-integrin expression is increased on the surface of SCD neutrophils and intermediates the recruitment of red blood cells to the vessel wall, in turn promoting vaso-occlusion [93, 124, 272, 273].

In addition to their important role in cellular and molecular inflammatory responses, neutrophils, in particular, but also monocytes, eosinophils and mast cells, can also respond to the presence of microorganisms and other stimuli including alterations in ROS balance by releasing extracellular traps (ETs) [274]. ET release consists of the ejection of decondensed chromatin through the ruptured cell membrane; this extruded DNA contains histones and granular enzymes, such as neutrophil elastase [274, 275]. While these ETs have a recognized importance as a defense mechanism against microorganisms, increasing evidence indicates a role for these structures in inflammatory and autoimmune diseases [276, 277]. Neutrophil ET (NET) formation has been reported in SCD [83, 278], and may play some role in SCD pathogenesis, with a crucial role for cell-free heme and TLR4 in this formation [83, 279].

Monocyte activation has also been reported in SCD and a role for these cells in endothelial activation in the disease has also been demonstrated $[141,280]$. Monocytes are important producers of pro-inflammatory cytokines [281], including TNF- $\alpha$ and IL-1 $\beta$ [280], and can also form heterocellular aggregates with RBCs and platelets [41, 282, 283], potentially contributing to vaso-occlusive processes. Two reports suggest that monocytes may be crucial to the production of TNF- $\alpha$ and IL-1 $\beta$ in SCD, which in turn have a critical function in endothelial activation [207, 280]. Furthermore, the exposure of murine macrophages to hemolytic RBCs or heme causes their functional phenotypic change toward a proinflammatory state [159] and the formation of the NLRP3 inflammasome [284] via activation of the TLR4 signaling pathway. Given the elevation in levels of the inflammasome-processing dependent cytokines, IL-1 $\beta$ and IL-18, in SCD [205, 221], it seems reasonable to presume that, in addition to a participation of activated neutrophils [285] in the processing of these cytokines, tissue macrophages and monocytes may also make some contribution.

Invariant natural killer $\mathrm{T}$ (iNKT) cells are a specialized subset of $\mathrm{T}$ cells that recognize both self and foreign lipids presented by CD1d and can play both harmful and protective pathological roles [286]. Patients with SCD present activation of circulating iNKT during painful vaso-occlusive episodes [287] and NY1DD sickle mice reportedly have more numerous and more activated iNKT cells in the lungs, liver and spleen than wild-type mice; furthermore, these cells participate in pulmonary inflammation by producing IFN- $\gamma$ and CXCR3 chemokines [103]. Moreover, pulmonary function in these mice is improved by depleting or neutralizing iNKT cells and their activity and the activation of adenosine $\mathrm{A}(2 \mathrm{~A})$ receptors (A(2A)Rs) on iNKT and NK cells in SCD mice can ameliorate baseline pulmonary function and prevent hypoxia-reoxygenation-induced exacerbation of pulmonary injury [288]. 
Platelet activation: Platelet activation [289-291] and alterations in platelet aggregation $[292,293]$ are characteristics of SCD; moreover, platelet activation appears to be further elevated during acute vaso-occlusive episodes [294], with augmented circulating levels of platelet microparticles and platelet-derived proteins, such as thrombospondin-1 and PF4, reflecting this activation in SCD [290, 295-297]. As well as their role in hemostasis, platelets are also major inflammatory cells [94]. The adhesion molecules, $a_{\text {iib }} \beta_{3}$ and Pselectin, are augmented on the surface of SCD platelets [96, 291, 298] making them more adhesive to components of the vascular wall [95, 291], with evidence that the adhesion of SCD platelets to endothelial cells induces their activation [95]. Additionally, platelets from SCD individuals produce high levels of inflammatory cytokines, such as LIGHT (TNFSF14) and CD40L [96, 97], with levels of CD40L being associated with the incidence of acute chest syndrome [219].

\section{Anti-inflammatory mechanisms in SCD}

The resolution of inflammation involves active innate biochemical mechanisms and antiinflammatory molecules that enable inflamed tissues to return to homeostasis [299]. In an attempt to counter the chronic inflammation in SCD, a number of anti-inflammatory molecules and pathways are up-regulated and these and others may potentially be exploited for therapeutic purposes. The IL-10 cytokine, produced principally by macrophages, $\mathrm{T}$ and B lymphocytes, natural killer cells and monocytes, is a class 2 cytokine that can limit the production of pro-inflammatory cytokines including TNF- $a$ and IL-1 $\beta$ [300, 301]. Levels of IL-10 are augmented in steady-state SCD [142, 143], but reduced (compared to steady-state) in patients in vaso-occlusive crisis [302].

The heme oxygenase-1 (HO-1) enzyme is an important antioxidant and anti-inflammatory molecule that catalytically cleaves heme groups to carbon monoxide, free iron, and biliverdin following its upregulation in response to heme and oxidative signals. HO-1 gene expression is up-regulated in SCD, probably as a result of hemolytic events [142, 303]. Gene delivery of HO-1 to the liver of SCD mice, inhibits local hypoxia-induced stasis [304], while the repeated administration of SCD mice with haptoglobin for three months increased HO-1 and $\mathrm{H}$-ferritin expression and decreased iron deposition in the kidney, although the changes during the period studied were unable to improve kidney function [305]. Importantly, HO-1catalyzed heme degradation can result in the generation of carbon monoxide (CO), which also has anti-inflammatory and anti-sickling properties [306-308]. CO can increase RBC survival, as well as decrease leukocytosis and NF- $\mathrm{kB}$ activation and upregulate antiinflammatory signaling pathways in SCD [149, 306, 309].

The Nuclear factor erythroid-2-related factor-2 (Nrf2) pathway also represents an antiinflammatory pathway whose activation may be beneficial in SCD. Nrf2 activation occurs in response to both oxidative and inflammatory stresses and orchestrates the recruitment of inflammatory cells and regulates gene expression, including HO-1, through the antioxidant response element (ARE) [310]. Nonhematopoietic Nrf2 displays a dominant protective role against tissue damage in mice with SCD and its prophylactic activation stabilizes intravascular hemolysis, reverses vascular inflammation and attenuates lung edema in these mice [311]. Furthermore, dimethyl fumarate (DMF), an activator of Nrf2-responsive genes 
and a drug approved for the treatment of multiple sclerosis, enhances antioxidant defenses and inhibits inflammation and vaso-occlusive processes in SCD mice, via an HO-1 dependent mechanism [312], while the administration of CDDO-Im (2-cyano-3, 12dioxooleana-1, 9diene-28-imidazolide) also relieves inflammation and organ failure in SCD mice [156]. Sleeping Beauty transposase plasmid delivery of either the human wildtype ferritin heavy chain (wt-hFHC) or hemopexin into SCD mice was able to enhance Nrf2regulated protein activity, including HO-1, resulting in decreased NF- $\kappa \mathrm{B}$ activation and vaso-occlusive processes in these mice [152, 158]. Importantly, Nrf2 activation also upregulates $\gamma$-globin gene transcription in erythroid cells, inducing HbF production, therefore representing a therapeutic target whose activation may have multiple benefits in SCD [313-315].

Polymerization of $\mathrm{HbS}$ in the deoxy conformation shortens the lifespan of SS-RBCs and promotes intravascular and extravascular hemolysis [55]. When SS-RBCs are lysed intravascularly, $\mathrm{HbS}$ is released into the vascular space where it can consume $\mathrm{NO}$ and be oxidized to higher oxidative forms [56, 316, 317]. During these reactions, ferric $\left(\mathrm{Fe}^{3+}\right)$ hemoglobin (metHb) is formed, which readily releases heme [74, 318-320]. Haptoglobin and hemopexin are plasma proteins with the highest binding affinities for hemoglobin $(\mathrm{Hb})$ $\left(\mathrm{K}_{\mathrm{d}}=\sim 10^{-12} \mathrm{M}\right)$ and heme $\left(\mathrm{K}_{\mathrm{d}}<10^{-13} \mathrm{M}\right)$, respectively [321]. Haptoglobin and hemopexin render $\mathrm{Hb}$ and heme relatively nonreactive [322-330] and deliver $\mathrm{Hb}$ and heme safely to CD163 receptors on macrophages [331, 332] and CD91 receptors on hepatocytes [333, 334], respectively, for endocytosis and degradation of their heme moieties by HO-1 [331, 334338]. Haptoglobin blocks $\mathrm{Hb}$ translocation into interstitial tissue spaces [339] and preserves vascular NO signaling during hemolysis and both haptoglobin and hemopexin can inhibit $\mathrm{Hb}$ - and heme-mediated microvascular stasis in SCD mice.

Albumin can complex with heme in vivo, especially in haptoglobin-depleted states such as $\operatorname{SCD}[318,340]$. However, endogenous circulating serum albumin in mice, which is $\sim 4 \mathrm{~g} / \mathrm{dL}$ [341] or $\sim 600 \mu \mathrm{M}$, does not prevent heme-mediated TLR4 activation and stasis in SS-mice in response to heme infusions as low as $0.32 \mu \mathrm{mol} / \mathrm{kg}$ or $\sim 5 \mu \mathrm{M}$ plasma heme [74]. This probably reflects albumin's much lower binding-affinity for heme $\left(\mathrm{K}_{\mathrm{d}}=\sim 4 \times 10^{-5} \mathrm{M}\right)$ versus hemopexin $\left(\mathrm{K}_{\mathrm{d}}<10^{-13} \mathrm{M}\right)$. Heme/hemopexin complexes predominate in sera when there is sufficient hemopexin [321, 342].

Plasma haptoglobin and hemopexin levels are often depleted in SCD patients and mice due to chronic intravascular hemolysis [84, 85, 158, 343, 344]. In animal models, increasing plasma haptoglobin or hemopexin can prevent organ toxicity caused by the $\mathrm{Hb}$ and heme released during hemolysis [158, 159, 324, 327, 343, 345-347]. Conversely, haptoglobin and hemopexin gene-null mice are especially prone to oxidative stress and inflammation [320, 345, 346, 348-353].

\section{Inflammation and acute painful vaso-occlusive episodes}

While subclinical vaso-occlusive processes occur constantly in the microcirculation of individuals with SCD, acute vaso-occlusive episodes (VOE) constitute episodic events that cause extreme pain, usually localized in the bones and joints, often leading to hospitalization 
for pain management [268]. Leukocyte counts have been consistently reported as elevated above baseline upon hospital admission of patients for acute pain events [354-356], and in vitro studies have demonstrated that neutrophils from patients hospitalized during pain events present indications of greater activation and are more adherent [357, 358]. Additionally elevated myeloperoxidase activity and circulating neutrophil MP levels are associated with acute VOE [359], indicating that an intensification of inflammatory processes occurs at the time of VOE onset. Of the inflammatory molecules known to be elevated during steady-state in SCD, there is some evidence that some of these are further elevated during acute VOE, including the cytokines CD40L, IL-6, and IL-18 [96, 216, 302] and chemokine IL-8 (CXCL8) [203, 360]. The acute phase proteins, substance P, [231] Creactive protein and pentraxin-3 [232] and the lipid chemoattractant, leukotriene B4 (LTB4) [361], are reported to also be further increased during VOE. In contrast, alterations in antiinflammatory molecules may occur in VOE, with IL-10 observed to be significantly decreased in VOE compared to levels in steady-state SCD individuals [302], while IL-4 has been reported as increased in SCD VOE, possibly reflecting shifts in $\mathrm{CD}^{+}: \mathrm{CD}^{+} \mathrm{T}$ cell ratios [362].

Lactate dehydrogenase has been suggested as a predictor of acute VOE severity [363] and cell-free heme is also increased during VOE [359], indicating that exacerbated hemolytic processes may be associated with these events [364]. Thus, given the critical role that inflammation has in driving the initiation and propagation of vaso-occlusive processes, it seems reasonable to assume that inflammatory processes may be the trigger for these acute painful VOEs, indeed in animal models, the administration of TNF- $a$, the neutrophil chemoattractant CXCL1, lipopolysaccharide (LPS), or exposure to hypoxia and reoxygenation induce severe inflammatory responses that culminate in experimental vasoocclusion $[74,83,93,125]$. However, despite the substantial data available that demonstrate the further generation of a plethora of inflammatory molecules in the circulation of SCD patients experiencing an acute painful episode, researchers have yet to convincingly describe a major inflammatory marker that may be indicative of an imminent acute event or provide a specific target for pharmacological reversal of the vaso-occlusive state in patients experiencing severe pain.

\section{Role for the gut and microbiome in sickle cell pathogenesis}

A huge diversity of microorganisms coexist with mammalian organisms, particularly in the intestine, and reports increasingly speculate that the microbiota may play a role in modulating inflammatory responses [365]. While the intestine has developed mechanisms to optimize protection to hosts against pathogens, this organ constitutes a primary site for foreign antigen encounter and microbial colonization [366]. Intestinal epithelial cells can detect bacterial antigens (or pathogen-associated molecular patterns, PAMPs), and initiate innate immune responses [367]. Immune cells in the vicinity, such as macrophages, dendritic cells and lymphocytes, can detect these PAMPs, which include LPS, peptidoglycan, and microbial nucleic acids, via receptors expressed on the epithelial cell surface, such as major histocompatibility complex I and II molecules and TLRs [368], in turn activating inflammatory pathways. Additionally, impaired intestinal barrier function may result in bacterial translocation, where the presence of bacterial products in the systemic circulation 
can potentially exacerbate the organism's inflammatory state [369]; indeed changes in the composition of intestinal microbiota have been associated with diseases such as atherosclerosis, hypertension, heart failure, chronic kidney disease, obesity, and type 2 diabetes mellitus [370].

In addition to the role of the intestinal microbiome in providing inflammatory stimuli, recent data suggest that food intake itself may induce inflammatory mechanisms, increasing the number of peritoneal macrophages and macrophage-derived IL- $1 \beta$ secretion, in a glucosedependent manner [371]. Furthermore lipids consumed in the diet (fatty acids, cholesterol, or fat-soluble vitamins) and oligoelements (such as zinc, copper, and iron) also have an effect on the immune system, where high fat-diets reduce both innate and adaptive immune responses by affecting the activity of macrophages, dendritic cells, and T lymphocytes [372], and zinc-deficiency can lead to immune dysfunction [373].

A recent demonstration of the influence of the microbiome on the immune system in SCD was provided by a study from Zhang et al [374]. Authors reported a role for the microbiota in driving neutrophil aging (and consequently increased activity) via TLR-mediated signaling. Data suggested that neutrophils constantly receive priming signals, derived from microbiota-derived molecules that cross the intestinal barrier, and become more active and more prone to release NETs as they age in the circulation. Importantly, the microbiota apparently also influence neutrophil aging and activity in SCD; depletion of the microbiota with antibiotics in both mice and humans with SCD significantly reduced the number of total neutrophils and circulating aged neutrophils and dramatically improved inflammationrelated organ damage in SCD mice [374]. Whether abnormalities in the integrity of the intestinal barriers or disequilibrium of the intestinal microbiota also occur in SCD, to amplify the effects of gut microbiota, is not known at present. However, while SCD is characterized by sterile inflammatory processes, PAMPs derived from microbiota and pathogens in the intestine may conceivably contribute to inflammatory processes in these individuals. For example, microbial-derived LPS in the gut may act as a priming signal for inflammasome formation in epithelial cells [365], which in the presence of sterile DAMPs may lead to IL-1 $\beta$ and IL-18 processing.

\section{Exercise and inflammation in sickle cell trait and disease}

In healthy individuals, exercise significantly increases oxygen consumption and oxygen flux in active muscles [375], occasioning ROS generation and ischemia-reperfusion stress, as well as modulating inflammatory responses [376]. Exercise can induce significant metabolic alterations, and acute bouts of exercise cause temporary increases in inflammatory markers and circulating adhesion molecule concentrations, due to the requirement for muscle healing and repair [377, 378]. In contrast, chronic exercise (repeated exercise for a prolonged period) provides healthy benefits in the general population with anti-inflammatory and antioxidant effects [379]. In the context of SCD, such acute exercise-induced changes may cause problematic physiological disturbances for patients, potentially increasing $\mathrm{HbS}$ polymerization and vaso-occlusive processes [380]. 
Sickle cell trait (SCT) is generally considered to be a benign disorder, but there are some reports of an increased risk of exercise-related sudden death in these individuals [381, 382], possibly due to hemorheological alterations, vascular cell adhesion mechanisms and the modulation of vascular function that may cause ischemia and muscle rhabdomyolysis [383]. Indeed, decreased red blood cell deformability and increased blood viscosity occur in SCT individuals during the recovery from exercise [384] and repeated heavy exercise bouts are reported to elevate circulating soluble(s) L-selectin and P-selectin kinetics and levels in SCT individuals, when compared to control individuals, possibly indicative of leukocyte and platelet activation [385]. In contrast, physically-active SCT individuals demonstrate reduced elevations in circulating sVCAM-1, compared to untrained SCT individuals, following an acute bout of exercise, indicating that a physically active lifestyle may decrease endothelial activation in SCT carriers and reduce the risk of vascular adhesive events in the microcirculation [386].

In SCD, it is still uncertain as to whether physical activity is safe, and many individuals with SCD may present limitations in their ability to exercise due to anemia or chronic complications such as pulmonary vascular disease, congestive heart failure and lung disease [387]. Hemorheological and hematological changes in SCD patients after mild-moderate exercise have been reported to be mild, except for the formation of dense cells, with authors suggesting that low-intensity exercise may not be harmful in SCD individuals that are able to carry out this activity [388]. In terms of the inflammatory response to exercise, there is some evidence that exercise may not be significantly more inflammatory in SCD than it is in healthy individuals. In children and young adults with SCA, who were subjected to maximal exercise testing, the acute phase response appeared to be elevated following exercise, as demonstrated by elevated C-reactive protein and D-dimer, compared to controls. However, alterations in markers of endothelial activation and inflammation were not significantly changed in response to exercise, when compared to matched controls [389]. In another study, NO levels, anti-oxidant capacity, sE-selectin and sP-selectin did not change in 11 patients subjected to mild-moderate exercise, sVCAM-1 levels were increased after exercise in both the SCA individuals and in the healthy control group, while sL-selectin decreased and sICAM-1 increased with exercise only in the SCA group [390]. Indeed, there is some evidence in mice with SCD that chronic exercise could be beneficial, both for reducing rheological alterations and for the inflammatory state. Mice with SCD subjected to 8 weeks of physical activity displayed an increased hematocrit-to-viscosity ratio and a lower blood viscosity, suggesting improvements in tissue perfusion and decreased vascular resistance [391]. Furthermore, sickle cell mice subjected to moderate training (treadmill training for 1 hour a day, 5 days a week) for 8 weeks demonstrated elevations in venous oxyhemoglobin, in association with reductions in the white cell count and the plasma Th1/Th2 cytokine ratio, as well as a reduced renal expression of the genes encoding IL-1 $\beta$ and endothelin-1 [392].

As such, further studies to understand why some carriers of SCT may be at greater risk from exertional death than others are needed [383], as well as to determine whether mild-tomoderate physical activity could be of benefit in SCD [379]. 


\section{Anti-inflammatory therapeutic approaches for SCD}

At present, therapeutic options for SCD are limited to hematopoietic stem cell transplantation (HSCT)[393], which is a curative option but of limited availability, chronic transfusion and hydroxyurea therapy, although the USA Food and Drug Administration have recently approved oral L-glutamine for use in SCD (https://www.fda.gov/Drugs/ InformationOnDrugs/ApprovedDrugs/ucm566097.htm). L-glutamine improves the redox potential of sickle RBC and, therefore, counters oxidative stress $[394,395]$ and the FDA has approved the use of this supplement on the basis that it reduced the frequency of sickle cell crises and hospitalization in a group of SCA patients in a randomized, double-blind, placebo-controlled, multi-center clinical trial (NCT01179217).

\section{Anti-inflammatory effects of hydroxyurea:}

Hydroxyurea (or hydroxycarbamide) is a cytostatic agent that significantly reduces the incidence of hospitalization, acute pain, acute chest syndrome and transfusion frequency in patients with $\mathrm{SCD}$, and may provide an alternative to chronic transfusion therapy in a subset of patients with abnormal transcranial Doppler (TCD) velocities and at risk of stroke [396399]. The compound acts principally by inducing the production of $\mathrm{HbF}$, consequently reducing sickle hemoglobin polymerization [400]. Additionally, hydroxyurea has major antiinflammatory properties, which may be due to both the downstream effects of the inhibition of $\mathrm{HbS}$ polymerization and due to direct anti-inflammatory effects. Hydroxyurea therapy significantly reduces leukocyte counts in patients with SCD, even before HbF elevation is observed [397], potentially reducing the amplitude of inflammatory responses in the disease. In addition, hydroxyurea lowers the expression and activity of adhesion molecules on the surface of RBCs, leukocytes and the endothelium in SCD [291, 401-405] and has been associated with decreased circulating concentrations of a number of inflammatory molecules, including endothelin-1, TNF- $\mathbf{a}$, IL-1 $\beta$, IL-17, and GM-CSF [142, 203, 225, 406408], in addition to increasing anti-inflammatory protein expressions [142].

Furthermore, recent data suggest that hydroxyurea may have direct effects that are independent of its ability to elevate $\mathrm{HbF}$ production. Hydroxyurea can act as a NO donor, in vivo [409], with potentially significant anti-inflammatory effects. The administration of a single dose of hydroxyurea decreased leukocyte recruitment to the microvasculature in SCD mice following an inflammatory stimulus, resulting in the inhibition of vaso-occlusive processes and prolonged animal survival following inflammatory stimulation, when used together with an amplifier of NO-cyclic guanosine monophosphate (cGMP) intracellular signaling [410]. Similarly, hydroxyurea, when given in a single dose to C57BL/6 mice, abolishes the effects of hemolysis on systemic inflammation and leukocyte recruitment in the microcirculation [249], indicating that hydroxyurea has HbF-independent and NO/ cGMP-dependent effects that may involve the neutralization of hemolytic insults and inflammatory events. 


\section{Other anti-inflammatory approaches under pre-clinical and clinical development for use in SCD:}

Therapeutic approaches for SCD include those that target $\mathrm{HbS}$ polymerization and those that target events downstream of $\mathrm{HbS}$ polymerization that aim to reduce the inflammatory processes that trigger vaso-occlusion [411]. Gene therapies under development for SCD intend to correct the genetic defect of the disease, or induce $\mathrm{HbF}$ production [412, 413]. To inhibit the polymerization of $\mathrm{HbS}, \mathrm{HbF}$ inducers such as thalidomide derivatives/hybrids, histone deacetylase (HDAC) inhibitors and metformin have been studied [414-417], while anti-sickling agents under study include 5HF (Aes-103) and GBT440, which modulate the oxygen affinity of $\mathrm{HbS}$ [418].

A huge number of anti-inflammatory drugs are currently under investigation as potential therapeutic approaches for SCA and some of these drugs are described here and are summarized in Table 2. With the aim of reducing leukocyte adhesion to the blood vessel wall and, therefore, halt the initiation of vaso-occlusive processes, the pan-selectin antagonist, rivipansel (GMI-1070), was developed with a view to decreasing leukocyte/ endothelial interactions, as well as the formation of heterocellular leukocyte aggregates, and for use at the onset of VOE. Phase II studies have shown that GMI-1070 improves clinical outcomes such as time to resolution of crisis, time to discharge, and opioid use [419-421]. Other anti-cell adhesion approaches include single dose intravenous immunoglobulin, modified heparins and poloxamer 188 [419, 422-424]. Crizanlizumab, a monoclonal antibody that neutralizes the activity of P-selectin (expressed on endothelial cells and platelets), in a phase 2 trial, reduced the incidence of SCD vaso-occlusive complications (pain, priapism, acute chest syndrome, sequestration) when used at higher doses [425]. In contrast, the anti-platelet agent, prasugrel hydrochloride, which irreversibly inhibits the P2Y12 receptors, while being apparently well tolerated and safe in SCD, failed to significantly reduce vaso-occlusive complications in a large group of children and adolescents when administered for up to 24 months [426].

Statins and TNF- $a$ antagonists may be useful for reducing endothelial activation. In a recent pilot trial, the treatment of SCD patients with simvastatin resulted in a significant reduction in the frequency of pain, oral analgesic use and circulating inflammatory markers [427], especially in individuals on hydroxyurea therapy. Given the probable major role of TNF- $a$ in initiating and propagating SCD vaso-occlusion, TNF-a blockers, such as etanercept or infliximab, could be of some benefit. In SCD mice, etanercept ameliorated blood biomarkers of inflammation, vaso-occlusive processes triggered by hypoxia/reoxygenation, endothelial activation and histopathologic liver injury, amongst other parameters [207]. iNKT cell depletants and A2AR agonists under development for SCD could also decrease inflammation by decreasing iNKT cell numbers and inflammatory activation [90, 428].

Hemoglobin and heme scavengers, such as plasma-purified haptoglobin or recombinant hemopexin, have successfully prevented vaso-occlusion and acute chest syndrome onset in SCD mouse models $[74,80]$. Sustained treatment of SCD mice with haptoglobin has been found to increase HO-1 and $\mathrm{H}$-ferritin expression and decrease iron deposition in the kidney, although these effects were not associated with improved kidney function [305]; in contrast hepatic overexpression of hemopexin also inhibits inflammation and vascular stasis in SCD 
mice [158]. Supplementation of SCD mice with purified plasma haptoglobin or hemopexin was shown to rapidly activate the Nrf2/HO-1 axis and inhibit inflammation and vasoocclusion in an HO-1-dependent manner [429]. Activation of Nrf2 with dimethylfumarate (DMF), enhances antioxidant defenses, and inhibits inflammation and vaso-occlusion in SCD mice, also in an HO-1-dependent manner [312]. Triterpenoids have been suggested as a potential approach for SCD and synthetic oleanane (derived from oleanolic acid) triterpenoids (SOTs) are known to exert anti-inflammatory effects through Nrf2 activation, leading to transcription of enzymes, including HO-1 [430].

Pegylated hemoglobin carbon monoxide (CO) carriers have also been investigated in preclinical and clinical investigations for use in SCD. Sanguinate ${ }^{\mathrm{TM}}$ releases $\mathrm{CO}$ while also delivering oxygen to hypoxic tissues and a Phase Ib trial to evaluate this molecule's safety, efficacy in SCD has been completed (NCT01848925), demonstrating an acceptable safety profile in SCD patients [431]. A Phase 2 study of the safety and effectiveness of Sanguinate ${ }^{\mathrm{TM}}$ in the treatment of vaso-occlusive crises is currently in the recruitment stage (NCT02411708). Release of CO by another pegylated-Hb, MP4CO, has demonstrated significant anti-inflammatory and cytoprotective effects in mice with $\mathrm{SCD}$, inducing hepatic HO-1 activity and inhibiting NF- $\mathrm{kB}$ activation and hypoxia-reoxygenation-induced microvascular stasis [149]. A Phase Ib single dose escalation study demonstrated MP4CO to be well tolerated in steady-state SCD [307, 432], although a planned phase 2 study to evaluate the use of this molecule in vaso-occlusive crisis has not gone ahead due to the loss of corporate funding [NCT01925001].

Preclinical studies in SCD show that amplification of NO-cGMP dependent signaling, in combination with hydroxyurea, or not, may be of therapeutic benefit. An inhibitor of phosphodiesterase 9 (PDE9), which is highly expressed in hematopoietic cells [433] and decreases the degradation of intracellular cGMP, reduces vaso-occlusive processes in a SCDmouse model [410]. A phase I study to investigate the safety and tolerability of PF-04447943, a PDE9 inhibitor, in steady-state SCD individuals, with and without coadministration of HU, has been completed (NCT 02114203), while a phase 1a study is currently being initiated to evaluate the safety and tolerability of another PDE9 inhibitor, IMR-687, in healthy individuals (NCT02998450). Alternatively, guanylate cyclase stimulators or activators may also represent an approach for amplifying NO signaling in SCD [434, 435].

\section{Conclusion}

Given the huge range of agents currently under pre-clinical and clinical investigation for use in SCD, it seems likely that the use of further anti-inflammatory approaches in addition to (or possibly even in place of) hydroxyurea will eventually be common practice for the treatment of SCD in those individuals for whom HSCT or gene therapy are not a viable option. The exact inflammatory pathway that may be the most promising therapeutic target has still not been defined, but it seems probable that anti-inflammatory drugs that ameliorate a broad range of inflammatory mechanisms, or neutralize important players in the SCD inflammatory scenario or specific inflammatory cell types may hold the key to providing benefits in these patients. However, while some of the causes and inflammatory pathways 
that instigate the chronic inflammatory state in SCD are now better understood, the inflammatory mechanisms that trigger acute vaso-occlusive episodes remain extremely obscure, probably due to the constraints of studying this particular event in patients and the limitations of animal models of study. More studies that focus on defining specific triggers for these episodes are needed, in order to better define those approaches that may best prevent these triggers and to support the development of drugs for treating hospitalized patients during vaso-occlusive crisis.

\section{Acknowledgments}

Nicola Conran is supported by research grants from Fapesp, Brazil (2014/19173-5 and 2014/009843). John Belcher is supported by NIH grant R01 HL114567-05 and a grant from CSL Behring.

\section{References}

[1]. Steinberg MH. Overview of sickle cell anemia pathophysiology In: Costa FF, Conran N, editors. Sickle cell anemia: From basic science to clinical practice. Switzerland: Springer International; 2016 p. 49-75.

[2]. Ballas SK, Lusardi M. Hospital readmission for adult acute sickle cell painful episodes: frequency, etiology, and prognostic significance. Am J Hematol. 2005;79(1):17-25. [PubMed: 15849770]

[3]. Ataga KI, Moore CG, Hillery CA, Jones S, Whinna HC, Strayhorn D, et al. Coagulation activation and inflammation in sickle cell disease-associated pulmonary hypertension. Haematologica. 2008;93(1):20-6. [PubMed: 18166781]

[4]. Brousse V, Buffet P, Rees D. The spleen and sickle cell disease: the sick(led) spleen. Br J Haematol. 2014;166(2):165-76. [PubMed: 24862308]

[5]. Hebbel RP. Ischemia-reperfusion injury in sickle cell anemia: relationship to acute chest syndrome, endothelial dysfunction, arterial vasculopathy, and inflammatory pain. Hematol Oncol Clin North Am. 2014;28(2):181-98. [PubMed: 24589261]

[6]. De Montalembert M, Wang W. Cerebrovascular complications in children with sickle cell disease. Handb Clin Neurol. 2013;113:1937-43. [PubMed: 23622417]

[7]. Minniti CP, Delaney KM, Gorbach AM, Xu D, Lee CC, Malik N, et al. Vasculopathy, inflammation, and blood flow in leg ulcers of patients with sickle cell anemia. Am J Hematol. 2014;89(1):1-6. [PubMed: 23963836]

[8]. Nath KA, Hebbel RP. Sickle cell disease: renal manifestations and mechanisms. Nat Rev Nephrol. 2015;11(3):161-71. [PubMed: 25668001]

[9]. Wandersee NJ, Hillery CA. Red blood cells and the vaso-occlusive process In: Costa FF, Conran N, editors. Sickle cell anemia: From basic science to clinical practice. New York: Springer Int; 2016 p. 49-74.

[10]. Franco RS, Palascak M, Thompson H, Rucknagel DL, Joiner CH. Dehydration of transferrin receptor-positive sickle reticulocytes during continuous or cyclic deoxygenation: role of $\mathrm{KCl}$ cotransport and extracellular calcium. Blood. 1996;88(11):4359-65. [PubMed: 8943873]

[11]. Rust MB, Alper SL, Rudhard Y, Shmukler BE, Vicente R, Brugnara C, et al. Disruption of erythroid $\mathrm{K}-\mathrm{Cl}$ cotransporters alters erythrocyte volume and partially rescues erythrocyte dehydration in SAD mice. J Clin Invest. 2007;117(6):1708-17. [PubMed: 17510708]

[12]. Steinberg MH, Eaton JW, Berger E, Coleman MB, Oelshlegel FJ. Erythrocyte calcium abnormalities and the clinical severity of sickling disorders. Br J Haematol. 1978;40(4):533-39. [PubMed: 728370]

[13]. Brugnara C, Bunn HF, Tosteson DC. Regulation of erythrocyte cation and water content in sickle cell anemia. Science. 1986;232(4748):388-90. [PubMed: 3961486]

[14]. Bartolucci P, Brugnara C, Teixeira-Pinto A, Pissard S, Moradkhani K, Jouault H, et al. Erythrocyte density in sickle cell syndromes is associated with specific clinical manifestations and hemolysis. Blood. 2012;120(15):3136-41. [PubMed: 22919030] 
[15]. Hebbel RP. Beyond hemoglobin polymerization: the red blood cell membrane and sickle disease pathophysiology. Blood. 1991;77(2):214-37. [PubMed: 1985689]

[16]. Ilboudo Y, Bartolucci P, Rivera A, Sedzro JC, Beaudoin M, Trudel M, et al. Genome-wide association study of erythrocyte density in sickle cell disease patients. Blood Cells Mol Dis. 2017;65:60-5. [PubMed: 28552477]

[17]. Giulivi C, Hochstein P, Davies KJ. Hydrogen peroxide production by red blood cells. Free Radic Biol Med. 1994;16(1):123-9. [PubMed: 8299988]

[18]. Hebbel RP. The sickle erythrocyte in double jeopardy: autoxidation and iron decompartmentalization. Semin Hematol. 1990;27(1):51-69. [PubMed: 2405496]

[19]. Repka T, Shalev O, Reddy R, Yuan J, Abrahamov A, Rachmilewitz EA, et al. Nonrandom association of free iron with membranes of sickle and beta-thalassemic erythrocytes. Blood. 1993;82(10):3204-10. [PubMed: 8219209]

[20]. Hebbel RP, Leung A, Mohandas N. Oxidation-induced changes in microrheologic properties of the red blood cell membrane. Blood. 1990;76(5):1015-20. [PubMed: 2393710]

[21]. Barodka VM, Nagababu E, Mohanty JG, Nyhan D, Berkowitz DE, Rifkind JM, et al. New insights provided by a comparison of impaired deformability with erythrocyte oxidative stress for sickle cell disease. Blood Cells Mol Dis. 2014;52(4):230-5. [PubMed: 24246527]

[22]. Hebbel RP, Ney PA, Foker W. Autoxidation, dehydration, and adhesivity may be related abnormalities of sickle erythrocytes. Am J Physiol. 1989;256(3 Pt 1):C579-83. [PubMed: 2923193]

[23]. George A, Pushkaran S, Konstantinidis DG, Koochaki S, Malik P, Mohandas N, et al. Erythrocyte NADPH oxidase activity modulated by Rac GTPases, PKC, and plasma cytokines contributes to oxidative stress in sickle cell disease. Blood. 2013;121(11):2099-107. [PubMed: 23349388]

[24]. Chien S, Usami S, Bertles JF. Abnormal rheology of oxygenated blood in sickle cell anemia. J Clin Invest. 1970;49(4):623-34. [PubMed: 5443167]

[25]. Bertles JF, Milner PF. Irreversibly sickled erythrocytes: a consequence of the heterogeneous distribution of hemoglobin types in sickle-cell anemia. J Clin Invest. 1968;47(8):1731-41. [PubMed: 5666109]

[26]. Parrow NL, Tu H, Nichols J, Violet PC, Pittman CA, Fitzhugh C, et al. Measurements of red cell deformability and hydration reflect $\mathrm{HbF}$ and $\mathrm{HbA} 2$ in blood from patients with sickle cell anemia. Blood Cells Mol Dis. 2017;65:41-50. [PubMed: 28472705]

[27]. Kaul DK, Fabry ME, Nagel RL. Vaso-occlusion by sickle cells: evidence for selective trapping of dense red cells. Blood. 1986;68(5):1162-6. [PubMed: 3768533]

[28]. McCurdy PR, Sherman AS. Irreversibly sickled cells and red cell survival in sickle cell anemia: a study with both DF32P and 51CR. Am J Med. 1978;64(2):253-8. [PubMed: 629275]

[29]. Schlegel RA, Prendergast TW, Williamson P. Membrane phospholipid asymmetry as a factor in erythrocyte-endothelial cell interactions. J Cell Physiol. 1985;123(2):215-8. [PubMed: 3980587]

[30]. Manodori AB, Barabino GA, Lubin BH, Kuypers FA. Adherence of phosphatidylserine-exposing erythrocytes to endothelial matrix thrombospondin. Blood. 2000;95(4):1293-300. [PubMed: 10666202]

[31]. Setty BN, Betal SG. Microvascular endothelial cells express a phosphatidylserine receptor: a functionally active receptor for phosphatidylserine-positive erythrocytes. Blood. 2008;111(2): 905-14. [PubMed: 17911385]

[32]. Yasin Z, Witting S, Palascak MB, Joiner CH, Rucknagel DL, Franco RS. Phosphatidylserine externalization in sickle red blood cells: associations with cell age, density, and hemoglobin F. Blood. 2003;102(1):365-70. [PubMed: 12609840]

[33]. Setty BN, Kulkarni S, Rao AK, Stuart MJ. Fetal hemoglobin in sickle cell disease: relationship to erythrocyte phosphatidylserine exposure and coagulation activation. Blood. 2000;96(3):1119-24. [PubMed: 10910931]

[34]. Whelihan MF, Lim MY, Mooberry MJ, Piegore MG, Ilich A, Wogu A, et al. Thrombin generation and cell-dependent hypercoagulability in sickle cell disease. J Thromb Haemost. 2016;14(10): 1941-52. [PubMed: 27430959] 
[35]. Hebbel RP, Boogaerts MA, Eaton JW, Steinberg MH. Erythrocyte adherence to endothelium in sickle-cell anemia. A possible determinant of disease severity. N Engl J Med. 1980;302(18):9925. [PubMed: 7366623]

[36]. Hebbel RP, Yamada O, Moldow CF, Jacob HS, White JG, Eaton JW. Abnormal adherence of sickle erythrocytes to cultured vascular endothelium: possible mechanism for microvascular occlusion in sickle cell disease. J Clin Invest. 1980;65(1):154-60. [PubMed: 7350195]

[37]. Wautier JL, Wautier MP. Molecular basis of erythrocyte adhesion to endothelial cells in diseases. Clin Hemorheol Microcirc. 2013;53(1-2):11-21. [PubMed: 22941965]

[38]. Conran N, Franco-Penteado CF, Costa FF. Newer aspects of the pathophysiology of sickle cell disease vaso-occlusion. Hemoglobin. 2009;33(1):1-16. [PubMed: 19205968]

[39]. Brousse V, Colin Y, Pereira C, Arnaud C, Odievre MH, Boutemy A, et al. Erythroid Adhesion Molecules in Sickle Cell Anaemia Infants: Insights Into Early Pathophysiology. EBioMedicine. 2015;2(2):154-7. [PubMed: 26137540]

[40]. Bennewitz MF, Jimenez MA, Vats R, Tutuncuoglu E, Jonassaint J, Kato GJ, et al. Lung vasoocclusion in sickle cell disease mediated by arteriolar neutrophil-platelet microemboli. JCI Insight. 2017;2(1):e89761. [PubMed: 28097236]

[41]. Chaar V, Picot J, Renaud O, Bartolucci P, Nzouakou R, Bachir D, et al. Aggregation of mononuclear and red blood cells through an $\{$ alpha $\} 4$ beta $\} 1-\mathrm{Lu} /$ basal cell adhesion molecule interaction in sickle cell disease. Haematologica. 2010;95(11):1841-8. [PubMed: 20562314]

[42]. Dominical VM, Samsel L, Nichols JS, Costa FF, McCoy JP, Jr., Conran N, et al. Prominent role of platelets in the formation of circulating neutrophil-red cell heterocellular aggregates in sickle cell anemia. Haematologica. 2014;99(11):e214-7. [PubMed: 25420284]

[43]. Polanowska-Grabowska R, Wallace K, Field JJ, Chen L, Marshall MA, Figler R, et al. P-selectinmediated platelet-neutrophil aggregate formation activates neutrophils in mouse and human sickle cell disease. Arterioscler Thromb Vasc Biol. 2010;30(12):2392-9. [PubMed: 21071696]

[44]. Hebbel RP, Key NS. Microparticles in sickle cell anaemia: promise and pitfalls. Br J Haematol. 2016;174(1):16-29. [PubMed: 27136195]

[45]. Westerman M, Porter JB. Red blood cell-derived microparticles: An overview. Blood Cells Mol Dis. 2016;59:134-9. [PubMed: 27282583]

[46]. Johnstone RM, Mathew A, Mason AB, Teng K. Exosome formation during maturation of mammalian and avian reticulocytes: evidence that exosome release is a major route for externalization of obsolete membrane proteins. J Cell Physiol. 1991;147(1):27-36. [PubMed: 2037622]

[47]. Allan D, Limbrick AR, Thomas P, Westerman MP. Release of spectrin-free spicules on reoxygenation of sickled erythrocytes. Nature. 1982;295(5850):612-3. [PubMed: 7057919]

[48]. Liu SC, Derick LH, Zhai S, Palek J. Uncoupling of the spectrin-based skeleton from the lipid bilayer in sickled red cells. Science. 1991;252(5005):574-6. [PubMed: 2020854]

[49]. Rubin O, Canellini G, Delobel J, Lion N, Tissot JD. Red blood cell microparticles: clinical relevance. Transfus Med Hemother. 2012;39(5):342-7. [PubMed: 23801926]

[50]. Camus SM, Gausseres B, Bonnin P, Loufrani L, Grimaud L, Charue D, et al. Erythrocyte microparticles can induce kidney vaso-occlusions in a murine model of sickle cell disease. Blood. 2012;120(25):5050-8. [PubMed: 22976952]

[51]. Rank BH, Moyer NL, Hebbel RP. Vesiculation of sickle erythrocytes during thermal stress. Blood. 1988;72(3):1060-3. [PubMed: 3416068]

[52]. Awojoodu AO, Keegan PM, Lane AR, Zhang Y, Lynch KR, Platt MO, et al. Acid sphingomyelinase is activated in sickle cell erythrocytes and contributes to inflammatory microparticle generation in SCD. Blood. 2014;124(12):1941-50. [PubMed: 25075126]

[53]. Camus SM, De Moraes JA, Bonnin P, Abbyad P, Le Jeune S, Lionnet F, et al. Circulating cell membrane microparticles transfer heme to endothelial cells and trigger vasoocclusions in sickle cell disease. Blood. 2015;125(24):3805-14. [PubMed: 25827830]

[54]. Bensinger TA, Gillette PN. Hemolysis in sickle cell disease. Arch Intern Med. 1974;133(4):62431. [PubMed: 4594397] 
[55]. Hebbel RP. Reconstructing sickle cell disease: a data-based analysis of the "hyperhemolysis paradigm" for pulmonary hypertension from the perspective of evidence-based medicine. Am J Hematol. 2011;86(2):123-54. [PubMed: 21264896]

[56]. Reiter CD, Wang X, Tanus-Santos JE, Hogg N, Cannon RO, 3rd, Schechter AN, et al. Cell-free hemoglobin limits nitric oxide bioavailability in sickle-cell disease. Nat Med. 2002;8(12):13839. [PubMed: 12426562]

[57]. Schaer DJ, Vinchi F, Ingoglia G, Tolosano E, Buehler PW. Haptoglobin, hemopexin, and related defense pathways-basic science, clinical perspectives, and drug development. Front Physiol. 2014;5:415. [PubMed: 25389409]

[58]. Tsoumani ME, Kalantzi KI, Goudevenos IA, Tselepis AD. Platelet-Mediated Inflammation in Cardiovascular Disease. Potential Role of Platelet-Endothelium Interactions. Current Vascular Pharmacology. 2012;10(5):539-49. [PubMed: 22338568]

[59]. Arndt H, Russell JB, Kurose I, Kubes P, Granger DN. Mediators of leukocyte adhesion in rat mesenteric venules elicited by inhibition of nitric oxide synthesis. Gastroenterology. 1993;105(3):675-80. [PubMed: 8395443]

[60]. Hossain M, Qadri SM, Liu L. Inhibition of nitric oxide synthesis enhances leukocyte rolling and adhesion in human microvasculature. J Inflamm (Lond). 2012;9(1):28. [PubMed: 22812684]

[61]. Wallace JL. Nitric oxide as a regulator of inflammatory processes. Mem Inst Oswaldo Cruz. 2005;100 Suppl 1:5-9.

[62]. Walley KR, McDonald TE, Higashimoto Y, Hayashi S. Modulation of proinflammatory cytokines by nitric oxide in murine acute lung injury. Am J Respir Crit Care Med. 1999;160(2):698-704. [PubMed: 10430748]

[63]. Almeida CB, Souza LE, Leonardo FC, Costa FT, Werneck CC, Covas DT, et al. Acute hemolytic vascular inflammatory processes are prevented by nitric oxide replacement or a single dose of hydroxyurea. Blood. 2015;126(6):711-20. [PubMed: 26019278]

[64]. Kuruppu S, Rajapakse NW, Dunstan RA, Smith AI. Nitric oxide inhibits the production of soluble endothelin converting enzyme-1. Mol Cell Biochem. 2014;396(1-2):49-54. [PubMed: 25226840]

[65]. Zuckerbraun BS, Shiva S, Ifedigbo E, Mathier MA, Mollen KP, Rao J, et al. Nitrite potently inhibits hypoxic and inflammatory pulmonary arterial hypertension and smooth muscle proliferation via xanthine oxidoreductase-dependent nitric oxide generation. Circulation. 2010;121(1):98-109. [PubMed: 20026772]

[66]. Seki J, Nishio M, Kato Y, Motoyama Y, Yoshida K. FK409, a new nitric-oxide donor, suppresses smooth muscle proliferation in the rat model of balloon angioplasty. Atherosclerosis. 1995;117(1):97-106. [PubMed: 8546759]

[67]. Bzowska M, Stalinska K, Mezyk-Kopec R, Wawro K, Duda K, Das S, et al. Exogenous nitric oxide inhibits shedding of ADAM17 substrates. Acta Biochim Pol. 2009;56(2):325-35. [PubMed: 19543557]

[68]. Solovey A, Kollander R, Milbauer LC, Abdulla F, Chen Y, Kelm RJ, Jr., et al. Endothelial nitric oxide synthase and nitric oxide regulate endothelial tissue factor expression in vivo in the sickle transgenic mouse. Am J Hematol. 2010;85(1):41-5. [PubMed: 20029945]

[69]. Bauer H, Jung T, Tsikas D, Stichtenoth DO, Frolich JC, Neumann C. Nitric oxide inhibits the secretion of T-helper 1- and T-helper 2-associated cytokines in activated human T cells. Immunology. 1997;90(2):205-11. [PubMed: 9135548]

[70]. Rubanyi GM, Ho EH, Cantor EH, Lumma WC, Botelho LH. Cytoprotective function of nitric oxide: inactivation of superoxide radicals produced by human leukocytes. Biochem Biophys Res Commun. 1991;181(3):1392-7. [PubMed: 1662497]

[71]. Leeuwenburgh C, Hardy MM, Hazen SL, Wagner P, Oh-ishi S, Steinbrecher UP, et al. Reactive nitrogen intermediates promote low density lipoprotein oxidation in human atherosclerotic intima. J Biol Chem. 1997;272(3):1433-6. [PubMed: 8999808]

[72]. Pacher P, Beckman JS, Liaudet L. Nitric oxide and peroxynitrite in health and disease. Physiol Rev. 2007;87(1):315-424. [PubMed: 17237348]

[73]. Ponka P Cell biology of heme. Am J Med Sci. 1999;318(4):241-56. [PubMed: 10522552] 
[74]. Belcher JD, Chen C, Nguyen J, Milbauer L, Abdulla F, Alayash AI, et al. Heme triggers TLR4 signaling leading to endothelial cell activation and vaso-occlusion in murine sickle cell disease. Blood. 2014;123(3):377-90. [PubMed: 24277079]

[75]. Figueiredo RT, Fernandez PL, Mourao-Sa DS, Porto BN, Dutra FF, Alves LS, et al. Characterization of heme as activator of Toll-like receptor 4. J Biol Chem. 2007;282(28):202219. [PubMed: 17502383]

[76]. Godefroy E, Liu Y, Shi P, Mitchell WB, Cohen D, Chou ST, et al. Altered heme-mediated modulation of dendritic cell function in sickle cell alloimmunization. Haematologica. 2016;101(9):1028-38. [PubMed: 27229712]

[77]. Hally KE, La Flamme AC, Larsen PD, Harding SA. Platelet Toll-like receptor (TLR) expression and TLR-mediated platelet activation in acute myocardial infarction. Thromb Res. 2017;158:815. [PubMed: 28783513]

[78]. De Filippo K, Dudeck A, Hasenberg M, Nye E, van Rooijen N, Hartmann K, et al. Mast cell and macrophage chemokines CXCL1/CXCL2 control the early stage of neutrophil recruitment during tissue inflammation. Blood. 2013;121(24):4930-7. [PubMed: 23645836]

[79]. Paul J, Lei J, Jha R, Nguyen J, Simone DA, Gupta K. Heme Induced Spinal Microglial Cell Activation By TLR4 and Endoplasmic Reticulum Stress in Sickle Mice. Blood. 2014;124(21): 452-.

[80]. Ghosh S, Adisa OA, Chappa P, Tan F, Jackson KA, Archer DR, et al. Extracellular hemin crisis triggers acute chest syndrome in sickle mice. J Clin Invest. 2013;123(11):4809-20. [PubMed: 24084741]

[81]. Rehani T, Mathson K, Belcher JD, Vercellotti GM, Slungaard A. Heme Potently Stimulates Tissue Factor Expression By Peripheral Blood Monocytes: A Novel Mechanism For Thrombosis In Intravascular Hemolytic Diseases. Blood. 2013;122(21):2215-.

[82]. Mathson K, Teena R, Belcher JD, Vercellotti GM, Slungaard A. Thiocyanate Blocks PeroxidaseDependent Extracellular Trap (ET) Formation By PMN and Eosinophils: Heme Is a Potent New Agonist For The ET Pathway. Blood. 2013;122(21):323.

[83]. Chen G, Zhang D, Fuchs TA, Manwani D, Wagner DD, Frenette PS. Heme-induced neutrophil extracellular traps contribute to the pathogenesis of sickle cell disease. Blood. 2014;123(24): 3818-27. [PubMed: 24620350]

[84]. Fertakis A, Panitsas G, Angelopoulos B. Serum haemopexin concentration in patients with various haemoglobinopathies. Effect of splenectomy. Acta Haematol. 1973;50(3):149-53. [PubMed: 4202095]

[85]. Muller-Eberhard U, Javid J, Liem HH, Hanstein A, Hanna M. Plasma concentrations of hemopexin, haptoglobin and heme in patients with various hemolytic diseases. Blood. 1968;32(5):811-5. [PubMed: 5687939]

[86]. Sikora J, Orlov SN, Furuya K, Grygorczyk R. Hemolysis is a primary ATP-release mechanism in human erythrocytes. Blood. 2014;124(13):2150-7. [PubMed: 25097178]

[87]. Sprague RS, Stephenson AH, Ellsworth ML. Red not dead: signaling in and from erythrocytes. Trends Endocrinol Metab. 2007;18(9):350-5. [PubMed: 17959385]

[88]. Idzko M, Ferrari D, Eltzschig HK. Nucleotide signalling during inflammation. Nature. 2014;509(7500):310-7. [PubMed: 24828189]

[89]. Idzko M, Ferrari D, Riegel AK, Eltzschig HK. Extracellular nucleotide and nucleoside signaling in vascular and blood disease. Blood. 2014;124(7):1029-37. [PubMed: 25001468]

[90]. Field JJ, Nathan DG, Linden J. The role of adenosine signaling in sickle cell therapeutics. Hematol Oncol Clin North Am. 2014;28(2):287-99. [PubMed: 24589267]

[91]. Zhang Y, Dai Y, Wen J, Zhang W, Grenz A, Sun H, et al. Detrimental effects of adenosine signaling in sickle cell disease. Nat Med. 2011;17(1):79-86. [PubMed: 21170046]

[92]. Kurantsin-Mills J, Klug PP, Lessin LS. Vaso-occlusion in sickle cell disease: pathophysiology of the microvascular circulation. Am J Pediatr Hematol Oncol. 1988;10(4):357-72. [PubMed: 3071170]

[93]. Turhan A, Weiss LA, Mohandas N, Coller BS, Frenette PS. Primary role for adherent leukocytes in sickle cell vascular occlusion: a new paradigm. Proc Natl Acad Sci U S A. 2002;99(5):304751. [PubMed: 11880644] 
[94]. Zhang D, Xu C, Manwani D, Frenette PS. Neutrophils, platelets, and inflammatory pathways at the nexus of sickle cell disease pathophysiology. Blood. 2016;127(7):801-9. [PubMed: 26758915]

[95]. Proenca-Ferreira R, Brugnerotto AF, Garrido VT, Dominical VM, Vital DM, Ribeiro Mde F, et al. Endothelial activation by platelets from sickle cell anemia patients. PLoS One. 2014;9(2):e89012. [PubMed: 24551209]

[96]. Lee SP, Ataga KI, Orringer EP, Phillips DR, Parise LV. Biologically active CD40 ligand is elevated in sickle cell anemia: potential role for platelet-mediated inflammation. Arterioscler Thromb Vasc Biol. 2006;26(7):1626-31. [PubMed: 16601237]

[97]. Garrido VT, Proenca-Ferreira R, Dominical VM, Traina F, Bezerra MA, de Mello MR, et al. Elevated plasma levels and platelet-associated expression of the pro-thrombotic and proinflammatory protein, TNFSF14 (LIGHT), in sickle cell disease. Br J Haematol. 2012;158(6): 788-97. [PubMed: 22775554]

[98]. Davila J, Manwani D, Vasovic L, Avanzi M, Uehlinger J, Ireland K, et al. A novel inflammatory role for platelets in sickle cell disease. Platelets. 2015; in press.

[99]. Kalogeris T, Baines CP, Krenz M, Korthuis RJ. Cell biology of ischemia/reperfusion injury. Int Rev Cell Mol Biol. 2012;298:229-317. [PubMed: 22878108]

[100]. Xu H, Wandersee NJ, Guo Y, Jones DW, Holzhauer SL, Hanson MS, et al. Sickle cell disease increases high mobility group box 1: a novel mechanism of inflammation. Blood. 2014;124(26): 3978-81. [PubMed: 25339362]

[101]. Adewoye AH, Klings ES, Farber HW, Palaima E, Bausero MA, McMahon L, et al. Sickle cell vaso-occlusive crisis induces the release of circulating serum heat shock protein-70. Am J Hematol. 2005;78(3):240-2. [PubMed: 15726596]

[102]. Tadie JM, Bae HB, Jiang S, Park DW, Bell CP, Yang H, et al. HMGB1 promotes neutrophil extracellular trap formation through interactions with Toll-like receptor 4. Am J Physiol Lung Cell Mol Physiol. 2013;304(5):L342-9. [PubMed: 23316068]

[103]. Wallace KL, Marshall MA, Ramos SI, Lannigan JA, Field JJ, Strieter RM, et al. NKT cells mediate pulmonary inflammation and dysfunction in murine sickle cell disease through production of IFN-gamma and CXCR3 chemokines. Blood. 2009;114(3):667-76. [PubMed: 19433855]

[104]. Nickel RS, Hsu LL. Clinical Manifestations of Sickle Cell Anemia: Infants and Children In: Costa FF, Conran N, editors. Sickle cell anemia: From basic science to clinical practice. Switzerland: Springer International; 2016 p. 213-29.

[105]. Chaturvedi S, DeBaun MR. Evolution of sickle cell disease from a life-threatening disease of children to a chronic disease of adults: The last 40 years. Am J Hematol. 2016;91(1):5-14. [PubMed: 26547630]

[106]. Li S, Huang X, Chen Z, Zhong H, Peng Q, Deng Y, et al. Neutrophil CD64 expression as a biomarker in the early diagnosis of bacterial infection: a meta-analysis. Int J Infect Dis. 2013;17(1):e12-23. [PubMed: 22940278]

[107]. Giamarellos-Bourboulis EJ, Raftogiannis M. The immune response to severe bacterial infections: consequences for therapy. Expert Rev Anti Infect Ther. 2012;10(3):369-80. [PubMed: 22397569]

[108]. Enwonwu CO, Lu M. Elevated plasma histamine in sickle cell anaemia. Clin Chim Acta. 1991;203(2-3):363-8. [PubMed: 1777995]

[109]. Masini E, Di Bello MG, Raspanti S, Sacchi TB, Maggi E, Mannaioni PF. Platelet aggregation and histamine release by immunological stimuli. Immunopharmacology. 1994;28(1):19-29. [PubMed: 7523332]

[110]. Jancinova V, Nosal R. Increased histamine content in Ca2+-ionophore A23187-activated human blood platelets. Platelets. 1998;9(3-4):203-6. [PubMed: 16793702]

[111]. Vincent L, Vang D, Nguyen J, Gupta M, Luk K, Ericson ME, et al. Mast cell activation contributes to sickle cell pathobiology and pain in mice. Blood. 2013;122(11):1853-62. [PubMed: 23775718] 
[112]. Tharp MD, Kagey-Sobotka A, Fox CC, Marone G, Lichtenstein LM, Sullivan TJ. Functional heterogeneity of human mast cells from different anatomic sites: in vitro responses to morphine sulfate. J Allergy Clin Immunol. 1987;79(4):646-53. [PubMed: 2435777]

[113]. Kopecky EA, Jacobson S, Joshi P, Koren G. Systemic exposure to morphine and the risk of acute chest syndrome in sickle cell disease. Clin Pharmacol Ther. 2004;75(3):140-6. [PubMed: 15001964]

[114]. Neumann D, Schneider EH, Seifert R. Analysis of histamine receptor knockout mice in models of inflammation. J Pharmacol Exp Ther. 2014;348(1):2-11. [PubMed: 24101735]

[115]. Hamilton KK, Sims PJ. Changes in cytosolic Ca2+ associated with von Willebrand factor release in human endothelial cells exposed to histamine. Study of microcarrier cell monolayers using the fluorescent probe indo-1. J Clin Invest. 1987;79(2):600-8. [PubMed: 3492515]

[116]. Wagner MC, Eckman JR, Wick TM. Histamine increases sickle erythrocyte adherence to endothelium. Br J Haematol. 2006;132(4):512-22. [PubMed: 16412024]

[117]. Guchhait P, Dasgupta SK, Le A, Yellapragada S, Lopez JA, Thiagarajan P. Lactadherin mediates sickle cell adhesion to vascular endothelial cells in flowing blood. Haematologica. 2007;92(9): 1266-7. [PubMed: 17768123]

[118]. Smeets MW, Bierings R, Meems H, Mul FP, Geerts D, Vlaar AP, et al. Platelet-independent adhesion of calcium-loaded erythrocytes to von Willebrand factor. PLoS One. 2017;12(3):e0173077. [PubMed: 28249049]

[119]. Tasaka K, Nakaya N, Code CF. Histamine leukocytosis. I. Effect of histamine on peripheral leukocyte counts. Methods Find Exp Clin Pharmacol. 1992;14(9):667-75. [PubMed: 1294856]

[120]. Ghosh AK, Hirasawa N, Ohtsu H, Watanabe T, Ohuchi K. Defective angiogenesis in the inflammatory granulation tissue in histidine decarboxylase-deficient mice but not in mast celldeficient mice. J Exp Med. 2002;195(8):973-82. [PubMed: 11956288]

[121]. Leite-de-Moraes MC, Diem S, Michel ML, Ohtsu H, Thurmond RL, Schneider E, et al. Cutting edge: histamine receptor $\mathrm{H} 4$ activation positively regulates in vivo IL-4 and IFN-gamma production by invariant NKT cells. J Immunol. 2009;182(3):1233-6. [PubMed: 19155466]

[122]. Ohtsu H Pathophysiologic role of histamine: evidence clarified by histidine decarboxylase gene knockout mice. Int Arch Allergy Immunol. 2012;158 Suppl 1:2-6. [PubMed: 22627359]

[123]. Swerlick RA, Eckman JR, Kumar A, Jeitler M, Wick TM. Alpha 4 beta 1-integrin expression on sickle reticulocytes: vascular cell adhesion molecule-1-dependent binding to endothelium. Blood. 1993;82(6):1891-9. [PubMed: 7691241]

[124]. Hofstra TC, Kalra VK, Meiselman HJ, Coates TD. Sickle erythrocytes adhere to polymorphonuclear neutrophils and activate the neutrophil respiratory burst. Blood. 1996;87(10): 4440-7. [PubMed: 8639806]

[125]. Kaul DK, Hebbel RP. Hypoxia/reoxygenation causes inflammatory response in transgenic sickle mice but not in normal mice. J Clin Invest. 2000;106(3):411-20. [PubMed: 10930444]

[126]. Wagener FA, Abraham NG, van Kooyk Y, de Witte T, Figdor CG. Heme-induced cell adhesion in the pathogenesis of sickle-cell disease and inflammation. Trends Pharmacol Sci. 2001;22(2): 52-4. [PubMed: 11166838]

[127]. Belcher JD, Bryant CJ, Nguyen J, Bowlin PR, Kielbik MC, Bischof JC, et al. Transgenic sickle mice have vascular inflammation. Blood. 2003;101(10):3953-9. [PubMed: 12543857]

[128]. Aslan M, Freeman BA. Oxidant-mediated impairment of nitric oxide signaling in sickle cell disease--mechanisms and consequences. Cellular \& Molecular Biology (Noisy-Le-Grand, France). 2004;50(1):95-105.

[129]. Jison ML, Munson PJ, Barb JJ, Suffredini AF, Talwar S, Logun C, et al. Blood mononuclear cell gene expression profiles characterize the oxidant, hemolytic, and inflammatory stress of sickle cell disease. Blood. 2004;104(1):270-80. [PubMed: 15031206]

[130]. Hebbel RP, Osarogiagbon R, Kaul D. The endothelial biology of sickle cell disease: inflammation and a chronic vasculopathy. Microcirculation. 2004;11(2):129-51. [PubMed: 15280088]

[131]. Lum AF, Wun T, Staunton D, Simon SI. Inflammatory potential of neutrophils detected in sickle cell disease. Am J Hematol. 2004;76(2):126-33. [PubMed: 15164377] 
[132]. Wagner MC, Eckman JR, Wick TM. Sickle cell adhesion depends on hemodynamics and endothelial activation. Journal of Laboratory \& Clinical Medicine. 2004;144(5):260-7; discussion 27-8. [PubMed: 15570244]

[133]. Wood K, Russell J, Hebbel RP, Granger DN. Differential expression of E- and P-selectin in the microvasculature of sickle cell transgenic mice. Microcirculation. 2004;11(4):377-85. [PubMed: 15280076]

[134]. Wood KC, Hebbel RP, Granger DN. Endothelial cell P-selectin mediates a proinflammatory and prothrombogenic phenotype in cerebral venules of sickle cell transgenic mice. Am J Physiol Heart Circ Physiol. 2004;286(5):H1608-14. [PubMed: 14704223]

[135]. Wood KC, Hebbel RP, Granger DN. Endothelial cell NADPH oxidase mediates the cerebral microvascular dysfunction in sickle cell transgenic mice. FASEB J. 2005;19(8):989-91. [PubMed: 15923406]

[136]. Mahaseth H, Vercellotti GM, Welch TE, Bowlin PR, Sonbol KM, Hsia CJ, et al. Polynitroxyl albumin inhibits inflammation and vasoocclusion in transgenic sickle mice. Journal of Laboratory \& Clinical Medicine. 2005;145(4):204-11.

[137]. Kaul DK, Kollander R, Mahaseth H, Liu XD, Solovey A, Belcher J, et al. Robust vascular protective effect of hydroxamic acid derivatives in a sickle mouse model of inflammation. Microcirculation. 2006;13(6):489-97. [PubMed: 16864415]

[138]. Okpala I Leukocyte adhesion and the pathophysiology of sickle cell disease. Curr Opin Hematol. 2006;13(1):40-4. [PubMed: 16319686]

[139]. Aslan M, Freeman BA. Redox-dependent impairment of vascular function in sickle cell disease. Free Radical Biology \& Medicine. 2007;43(11):1469-83. [PubMed: 17964418]

[140]. Krajewski ML, Hsu LL, Gladwin MT. The proverbial chicken or the egg? Dissection of the role of cell-free hemoglobin versus reactive oxygen species in sickle cell pathophysiology. American Journal of Physiology: Heart \& Circulatory Physiology. 2008;295(1):H4-7. [PubMed: 18502905]

[141]. Zennadi R, Chien A, Xu K, Batchvarova M, Telen MJ. Sickle red cells induce adhesion of lymphocytes and monocytes to endothelium. Blood. 2008;112(8):3474-83. [PubMed: 18664622]

[142]. Lanaro C, Franco-Penteado CF, Albuqueque DM, Saad ST, Conran N, Costa FF. Altered levels of cytokines and inflammatory mediators in plasma and leukocytes of sickle cell anemia patients and effects of hydroxyurea therapy. J Leukoc Biol. 2009;85(2):235-42. [PubMed: 19004988]

[143]. Niu X, Nouraie M, Campbell A, Rana S, Minniti CP, Sable C, et al. Angiogenic and inflammatory markers of cardiopulmonary changes in children and adolescents with sickle cell disease. PLoS One. 2009;4(11):e7956. [PubMed: 19956689]

[144]. Rusanova I, Escames G, Cossio G, de Borace RG, Moreno B, Chahboune M, et al. Oxidative stress status, clinical outcome, and beta-globin gene cluster haplotypes in pediatric patients with sickle cell disease. Eur J Haematol. 2010;85(6):529-37. [PubMed: 20846340]

[145]. Kanavaki I, Makrythanasis P, Lazaropoulou C, Kattamis A, Tzanetea R, Kalotychou V, et al. Adhesion molecules and high-sensitivity C-reactive protein levels in patients with sickle cell beta-thalassaemia. Eur J Clin Invest. 2011.

[146]. Setty BN, Key NS, Rao AK, Gayen-Betal S, Krishnan S, Dampier CD, et al. Tissue factorpositive monocytes in children with sickle cell disease: correlation with biomarkers of haemolysis. Br J Haematol. 2012;157(3):370-80. [PubMed: 22360627]

[147]. Chantrathammachart P, Mackman N, Sparkenbaugh E, Wang JG, Parise LV, Kirchhofer D, et al. Tissue factor promotes activation of coagulation and inflammation in a mouse model of sickle cell disease. Blood. 2012;120(3):636-46. [PubMed: 22661702]

[148]. Vinchi F, De Franceschi L, Ghigo A, Townes T, Cimino J, Silengo L, et al. Hemopexin Therapy Improves Cardiovascular Function by Preventing Heme-Induced Endothelial Toxicity in Mouse Models of Hemolytic Diseases. Circulation. 2013; 127(12):1317-29. [PubMed: 23446829]

[149]. Belcher JD, Young M, Chen C, Nguyen J, Burhop K, Tran P, et al. MP4CO, a pegylated hemoglobin saturated with carbon monoxide, is a modulator of HO-1, inflammation, and vasoocclusion in transgenic sickle mice. Blood. 2013;122(15):2757-64. [PubMed: 23908468]

[150]. Sparkenbaugh EM, Chantrathammachart P, Mickelson J, van Ryn J, Hebbel RP, Monroe DM, et al. Differential contribution of FXa and thrombin to vascular inflammation in a mouse model of sickle cell disease. Blood. 2014;123(11):1747-56. [PubMed: 24449213] 
[151]. Vercellotti GM, Belcher JD. Not simply misshapen red cells: multimolecular and cellular events in sickle vaso-occlusion. J Clin Invest. 2014;124(4):1462-5. [PubMed: 24642460]

[152]. Vercellotti GM, Khan FB, Nguyen J, Chen C, Bruzzone CM, Bechtel H, et al. H-ferritin ferroxidase induces cytoprotective pathways and inhibits microvascular stasis in transgenic sickle mice. Front Pharmacol. 2014;5:79. [PubMed: 24860503]

[153]. Xu H, Wandersee NJ, Guo Y, Jones DW, Holzhauer SL, Hanson MS, et al. Sickle cell disease increases high mobility group box 1: a novel mechanism of inflammation. 2014;124(26):397881.

[154]. Arumugam PI, Mullins ES, Shanmukhappa SK, Monia BP, Loberg A, Shaw MA, et al. Genetic diminution of circulating prothrombin ameliorates multiorgan pathologies in sickle cell disease mice. Blood. 2015;126(15):1844-55. [PubMed: 26286849]

[155]. van Beers EJ, Yang Y, Raghavachari N, Tian X, Allen DT, Nichols JS, et al. Iron, inflammation, and early death in adults with sickle cell disease. Circ Res. 2015;116(2):298-306. [PubMed: 25378535]

[156]. Keleku-Lukwete N, Suzuki M, Otsuki A, Tsuchida K, Katayama S, Hayashi M, et al. Amelioration of inflammation and tissue damage in sickle cell model mice by Nrf2 activation. Proc Natl Acad Sci U S A. 2015;112(39):12169-74. [PubMed: 26371321]

[157]. Charrin E, Ofori-Acquah SF, Nader E, Skinner S, Connes P, Pialoux V, et al. Inflammatory and oxidative stress phenotypes in transgenic sickle cell mice. Blood Cells, Molecules, \& Diseases. 2016;62:13-21.

[158]. Vercellotti GM, Zhang P, Nguyen J, Abdulla F, Chen C, Nguyen P, et al. Hepatic Overexpression of Hemopexin Inhibits Inflammation and Vascular Stasis in Murine Models of Sickle Cell Disease. Mol Med. 2016;22:437-451. [PubMed: 27451971]

[159]. Vinchi F, Costa da Silva M, Ingoglia G, Petrillo S, Brinkman N, Zuercher A, et al. Hemopexin therapy reverts heme-induced proinflammatory phenotypic switching of macrophages in a mouse model of sickle cell disease. Blood. 2016;127(4):473-86. [PubMed: 26675351]

[160]. Belcher JD, Mahaseth H, Welch TE, Otterbein LE, Hebbel RP, Vercellotti GM. Heme oxygenase- 1 is a modulator of inflammation and vaso-occlusion in transgenic sickle mice. J Clin Invest. 2006;116(3):808-16. [PubMed: 16485041]

[161]. Belcher JD, Chen C, Nguyen J, Zhang P, Abdulla F, Nguyen P, et al. Control of Oxidative Stress and Inflammation in Sickle Cell Disease with the Nrf2 Activator Dimethyl Fumarate. Antioxid Redox Signal. 2016.

[162]. Itokua KE, Makulo JR, Lepira FB, Aloni MN, Ekulu PM, Sumaili EK, et al. Albuminuria, serum antioxidant enzyme levels and markers of hemolysis and inflammation in steady state children with sickle cell anemia. BMC Nephrol. 2016;17(1):178. [PubMed: 27855647]

[163]. El-Ghamrawy MK, Hanna WM, Abdel-Salam A, El-Sonbaty MM, Youness ER, Adel A. Oxidant-antioxidant status in Egyptian children with sickle cell anemia: a single center based study. J Pediatr (Rio J). 2014;90(3):286-92. [PubMed: 24508012]

[164]. Sess D, Carbonneau MA, Thomas MJ, Dumon MF, Peuchant E, Perromat A, et al. [First observations on the main plasma parameters of oxidative stress in homozygous sickle cell disease]. Bull Soc Pathol Exot. 1992;85(2):174-9. [PubMed: 1327359]

[165]. Hasanato RM. Zinc and antioxidant vitamin deficiency in patients with severe sickle cell anemia. Ann Saudi Med. 2006;26(1):17-21. [PubMed: 16521870]

[166]. Amer J, Ghoti H, Rachmilewitz E, Koren A, Levin C, Fibach E. Red blood cells, platelets and polymorphonuclear neutrophils of patients with sickle cell disease exhibit oxidative stress that can be ameliorated by antioxidants. Br J Haematol. 2006;132(1):108-13. [PubMed: 16371026]

[167]. Natta CL, Chen LC, Chow CK. Selenium and glutathione peroxidase levels in sickle cell anemia. Acta Haematol. 1990;83(3):130-2. [PubMed: 2109451]

[168]. Varma RN, Mankad VN, Phelps DD, Jenkins LD, Suskind RM. Depressed erythrocyte glutathione reductase activity in sickle cell disease. Am J Clin Nutr. 1983;38(6):884-7. [PubMed: 6650447]

[169]. Morris CR, Suh JH, Hagar W, Larkin S, Bland DA, Steinberg MH, et al. Erythrocyte glutamine depletion, altered redox environment, and pulmonary hypertension in sickle cell disease. Blood. 2008;111(1):402-10. [PubMed: 17848621] 
[170]. Ren H, Ghebremeskel K, Okpala I, Lee A, Ibegbulam O, Crawford M. Patients with sickle cell disease have reduced blood antioxidant protection. Int J Vitam Nutr Res. 2008;78(3):139-47. [PubMed: 19003736]

[171]. Alsultan AI, Seif MA, Amin TT, Naboli M, Alsuliman AM. Relationship between oxidative stress, ferritin and insulin resistance in sickle cell disease. European Review for Medical \& Pharmacological Sciences. 2010;14(6):527-38. [PubMed: 20712260]

[172]. Gizi A, Papassotiriou I, Apostolakou F, Lazaropoulou C, Papastamataki M, Kanavaki I, et al. Assessment of oxidative stress in patients with sickle cell disease: The glutathione system and the oxidant-antioxidant status. Blood Cells, Molecules, \& Diseases. 2011;46(3):220-5.

[173]. Hebbel RP, Morgan WT, Eaton JW, Hedlund BE. Accelerated autoxidation and heme loss due to instability of sickle hemoglobin. Proc Natl Acad Sci U S A. 1988;85(1):237-41. [PubMed: 3422420]

[174]. Repka T, Hebbel RP. Hydroxyl radical formation by sickle erythrocyte membranes: role of pathologic iron deposits and cytoplasmic reducing agents. Blood. 1991;78(10):2753-8. [PubMed: 1668610]

[175]. Marcal LE, Dias-da-Motta PM, Rehder J, Mamoni RL, Blotta MH, Whitney CB, et al. Upregulation of NADPH oxidase components and increased production of interferon-gamma by leukocytes from sickle cell disease patients. Am J Hematol. 2008;83(1):41-5. [PubMed: 17654682]

[176]. Musicki B, Liu T, Sezen SF, Burnett AL. Targeting NADPH Oxidase Decreases Oxidative Stress in the Transgenic Sickle Cell Mouse Penis. The Journal of Sexual Medicine. 2012;9(8): 1980-7. [PubMed: 22620981]

[177]. Aslan M, Ryan TM, Adler B, Townes TM, Parks DA, Thompson JA, et al. Oxygen radical inhibition of nitric oxide-dependent vascular function in sickle cell disease. Proc Natl Acad Sci U S A. 2001;98(26):15215-20. [PubMed: 11752464]

[178]. Aslan M, Canatan D. Modulation of redox pathways in neutrophils from sickle cell disease patients. Exp Hematol. 2008;36(11):1535-44. [PubMed: 18809239]

[179]. Kassa T, Jana S, Strader MB, Meng F, Jia Y, Wilson MT, et al. Sickle Cell Hemoglobin in the Ferryl State Promotes betaCys-93 Oxidation and Mitochondrial Dysfunction in Epithelial Lung Cells (E10). J Biol Chem. 2015;290(46):27939-58. [PubMed: 26396189]

[180]. Bivalacqua TJ, Musicki B, Hsu LL, Berkowitz DE, Champion HC, Burnett AL. Sildenafil citrate-restored eNOS and PDE5 regulation in sickle cell mouse penis prevents priapism via control of oxidative/nitrosative stress. PLoS One. 2013;8(7):e68028. [PubMed: 23844149]

[181]. Wun T, Brunson A. Sickle cell disease: an inherited thrombophilia. Am Soc Hematol Educ Program. 2016;2016(1):640-7.

[182]. Noubouossie DC, Le PQ, Rozen L, Ziereisen F, Willems D, Demulder A, et al. Thrombin generation in children with sickle cell disease: relationship with age, hemolysis, transcranial Doppler velocity, and hydroxyurea treatment. Eur J Haematol. 2013;91(1):46-54. [PubMed: 23530655]

[183]. Peters M, Plaat BE, ten Cate H, Wolters HJ, Weening RS, Brandjes DP. Enhanced thrombin generation in children with sickle cell disease. Thromb Haemost. 1994;71(2):169-72. [PubMed: 8191393]

[184]. Stuart MJ, Setty BN. Hemostatic alterations in sickle cell disease: relationships to disease pathophysiology. Pediatr Pathol Mol Med. 2001;20(1):27-46. [PubMed: 12673843]

[185]. Francis RB, Jr. Elevated fibrin D-dimer fragment in sickle cell anemia: evidence for activation of coagulation during the steady state as well as in painful crisis. Haemostasis. 1989;19(2):10511. [PubMed: 2731776]

[186]. Shet AS, Aras O, Gupta K, Hass MJ, Rausch DJ, Saba N, et al. Sickle blood contains tissue factor-positive microparticles derived from endothelial cells and monocytes. Blood. 2003;102(7): 2678-83. [PubMed: 12805058]

[187]. Key NS, Slungaard A, Dandelet L, Nelson SC, Moertel C, Styles LA, et al. Whole blood tissue factor procoagulant activity is elevated in patients with sickle cell disease. Blood. 1998;91(11): 4216-23. [PubMed: 9596669] 
[188]. Solovey A, Kollander R, Shet A, Milbauer LC, Choong S, Panoskaltsis-Mortari A, et al. Endothelial cell expression of tissue factor in sickle mice is augmented by hypoxia/reoxygenation and inhibited by lovastatin. Blood. 2004;104(3):840-6. [PubMed: 15073034]

[189]. Colella MP, de Paula EV, Machado-Neto JA, Conran N, Annichino-Bizzacchi JM, Costa FF, et al. Elevated hypercoagulability markers in hemoglobin SC disease. Haematologica. 2015;100(4): 466-71. [PubMed: 25596272]

[190]. Francis WG, Womack CR. Serum complement activity in normal individuals and patients with sickle cell hemoglobin abnormalities. Am J Med Technol. 1967;33(2):77-86. [PubMed: 6041787]

[191]. Johnston RB, Jr., Newman SL, Struth AG. An abnormality of the alternate pathway of complement activation in sickle-cell disease. N Engl J Med. 1973;288(16):803-8. [PubMed: 4144343]

[192]. Merle N, Church SE, Fremeaux-Bacchi V, Roumenina LT. Complement system part I molecular mechanisms of activation and regulation. Frontiers in Immunology. 2015;6:262. [PubMed: 26082779]

[193]. Krisinger MJ, Goebeler V, Lu Z, Meixner SC, Myles T, Pryzdial EL, et al. Thrombin generates previously unidentified $\mathrm{C} 5$ products that support the terminal complement activation pathway. Blood. 2012;120(8):1717-25. [PubMed: 22802338]

[194]. Zecher D, Cumpelik A, Schifferli JA. Erythrocyte-derived microvesicles amplify systemic inflammation by thrombin-dependent activation of complement. Art Throm Vasc Biol. 2014;34(2):313-20.

[195]. Chudwin DS, Papierniak C, Lint TF, Korenblit AD. Activation of the alternative complement pathway by red blood cells from patients with sickle cell disease. Clin Immunol Immunopath. 1994;71(2):199-202.

[196]. Mold C, Tamerius JD, Phillips G, Jr. Complement activation during painful crisis in sickle cell anemia. Clinical Immunology \& Immunopathology. 1995;76(3 Pt 1):314-20. [PubMed: 7554454]

[197]. Chudwin DS, Korenblit AD, Kingzette M, Artrip S, Rao S. Increased activation of the alternative complement pathway in sickle cell disease. Clin Immunol Immunopath. 1985;37(1): 93-7.

[198]. Wang RH, Phillips G, Jr., Medof ME, Mold C. Activation of the alternative complement pathway by exposure of phosphatidylethanolamine and phosphatidylserine on erythrocytes from sickle cell disease patients. J Clin Invest. 1993;92(3):1326-35. [PubMed: 7690777]

[199]. Nilsson B, Nilsson Ekdahl K. The tick-over theory revisited: is C3 a contact-activated protein? Immunobiology. 2012;217(11):1106-10. [PubMed: 22964236]

[200]. Zwaal RF, Schroit AJ. Pathophysiologic implications of membrane phospholipid asymmetry in blood cells. Blood. 1997;89(4):1121-32. [PubMed: 9028933]

[201]. Test ST, Woolworth VS. Defective regulation of complement by the sickle erythrocyte: evidence for a defect in control of membrane attack complex formation. Blood. 1994;83(3):842-52. [PubMed: 7507737]

[202]. Schaid TR, Nguyen J, Chen C, Abdulla F, Killeen T, Nguyen H, et al. Complement Activation in a Murine Model of Sickle Cell Disease: Inhibition of Vaso-Occlusion By Blocking C5 Activation. Blood. 2016;128(22):158.

[203]. Keikhaei B, Mohseni AR, Norouzirad R, Alinejadi M, Ghanbari S, Shiravi F, et al. Altered levels of pro-inflammatory cytokines in sickle cell disease patients during vaso-occlusive crises and the steady state condition. Eur Cytokine Netw. 2013;24(1):45-52. [PubMed: 23608554]

[204]. Pathare A, Kindi SA, Daar S, Dennison D. Cytokines in sickle cell disease. Hematology. 2003;8(5):329-37. [PubMed: 14530175]

[205]. Qari MH, Dier U, Mousa SA. Biomarkers of inflammation, growth factor, and coagulation activation in patients with sickle cell disease. Clin Appl Thromb Hemost. 2012;18(2):195-200. [PubMed: 21949038]

[206]. Turhan A, Jenab P, Bruhns P, Ravetch JV, Coller BS, Frenette PS. Intravenous immune globulin prevents venular vaso-occlusion in sickle cell mice by inhibiting leukocyte adhesion and the 
interactions between sickle erythrocytes and adherent leukocytes. Blood. 2004;103(6):2397-400. [PubMed: 14630831]

[207]. Solovey A, Somani A, Belcher JD, Milbauer L, Vincent L, Pawlinski R, et al. A monocyteTNF-endothelial activation axis in sickle transgenic mice: Therapeutic benefit from TNF blockade. Am J Hematol. 2017;92(11):1119-30. [PubMed: 28699284]

[208]. Silveira AAA, Dominical VM, Almeida CB, Chweih H, Ferreira WA, Jr., Vicente CP, et al. TNF induces neutrophil adhesion via formin-dependent cytoskeletal reorganization and activation of beta-integrin function. J Leukoc Biol. 2017; in press.

[209]. Li J, Yin Q, Wu H. Structural basis of signal transduction in the TNF receptor superfamily. Adv Immunol. 2013;119:135-53. [PubMed: 23886067]

[210]. Chappell D, Hofmann-Kiefer K, Jacob M, Rehm M, Briegel J, Welsch U, et al. TNF-alpha induced shedding of the endothelial glycocalyx is prevented by hydrocortisone and antithrombin. Basic Res Cardiol. 2009;104(1):78-89. [PubMed: 18836678]

[211]. van Beers EJ, Nieuwdorp M, Duits AJ, Evers LM, Schnog JJ, Biemond BJ, et al. Sickle cell patients are characterized by a reduced glycocalyx volume. Haematologica. 2008;93(2):307-8. [PubMed: 18245656]

[212]. Gao X, Xu X, Belmadani S, Park Y, Tang Z, Feldman AM, et al. TNF-alpha contributes to endothelial dysfunction by upregulating arginase in ischemia/reperfusion injury. Arterioscler Thromb Vasc Biol. 2007;27(6):1269-75. [PubMed: 17413034]

[213]. Lo SK, Van Seventer GA, Levin SM, Wright SD. Two leukocyte receptors (CD11a/CD18 and $\mathrm{CD} 11 \mathrm{~b} / \mathrm{CD} 18$ ) mediate transient adhesion to endothelium by binding to different ligands. $\mathrm{J}$ Immunol. 1989;143(10):3325-9. [PubMed: 2809204]

[214]. Driss A, Wilson NO, Mason K, Hyacinth HI, Hibbert JM, Serjeant GR, et al. Elevated IL-1alpha and CXCL10 serum levels occur in patients with homozygous sickle cell disease and a history of acute splenic sequestration. Dis Markers. 2012;32(5):295-300. [PubMed: 22674409]

[215]. Francis RB, Jr., Haywood LJ. Elevated immunoreactive tumor necrosis factor and interleukin-1 in sickle cell disease. J Natl Med Assoc. 1992;84(7):611-5. [PubMed: 1629925]

[216]. Pathare A, Al Kindi S, Alnaqdy AA, Daar S, Knox-Macaulay H, Dennison D. Cytokine profile of sickle cell disease in Oman. Am J Hematol. 2004;77(4):323-8. [PubMed: 15551290]

[217]. Sakamoto TM, Lanaro C, Ozelo MC, Garrido VT, Olalla-Saad ST, Conran N, et al. Increased adhesive and inflammatory properties in blood outgrowth endothelial cells from sickle cell anemia patients. Microvasc Res. 2013;90:173-9. [PubMed: 24144783]

[218]. Xing Z, Gauldie J, Cox G, Baumann H, Jordana M, Lei XF, et al. IL-6 is an antiinflammatory cytokine required for controlling local or systemic acute inflammatory responses. J Clin Invest. 1998;101(2):311-20. [PubMed: 9435302]

[219]. Garrido VT, Sonzogni L, Mtatiro SN, Costa FF, Conran N, Thein SL. Association of plasma CD40L with acute chest syndrome in sickle cell anemia. Cytokine. 2017;97:104-7. [PubMed: 28609750]

[220]. Asare K, Gee BE, Stiles JK, Wilson NO, Driss A, Quarshie A, et al. Plasma interleukin-1beta concentration is associated with stroke in sickle cell disease. Cytokine. 2010;49(1):39-44. [PubMed: 19900820]

[221]. Cerqueira BA, Boas WV, Zanette AD, Reis MG, Goncalves MS. Increased concentrations of IL-18 and uric acid in sickle cell anemia: contribution of hemolysis, endothelial activation and the inflammasome. Cytokine. 2011;56(2):471-6. [PubMed: 21871815]

[222]. Pallis FR, Conran N, Fertrin KY, Olalla Saad ST, Costa FF, Franco-Penteado CF. Hydroxycarbamide reduces eosinophil adhesion and degranulation in sickle cell anaemia patients. Br J Haematol. 2014;164(2):286-95. [PubMed: 24383847]

[223]. Croizat H, Nagel RL. Circulating cytokines response and the level of erythropoiesis in sickle cell anemia. Am J Hematol. 1999;60(2):105-15. [PubMed: 9929101]

[224]. Unal S, Ozdemir O, Ozcimen AA, Oztas Y. Increase of serum fractalkine and fractalkine gene expression levels in sickle cell disease patients. Int J Hematol. 2015;101(2):114-8. [PubMed: 25480631] 
[225]. Conran N, Saad ST, Costa FF, Ikuta T. Leukocyte numbers correlate with plasma levels of granulocyte-macrophage colony-stimulating factor in sickle cell disease. Ann Hematol. 2007;86(4):255-61. [PubMed: 17205286]

[226]. Cruz PR, Lira RP, Pereira Filho SA, Souza BB, Mitsuushi FN, Menaa F, et al. Increased circulating PEDF and low sICAM-1 are associated with sickle cell retinopathy. Blood Cells Mol Dis. 2015;54(1):33-7. [PubMed: 25172543]

[227]. Brittain JE, Hulkower B, Jones SK, Strayhorn D, De Castro L, Telen MJ, et al. Placenta growth factor in sickle cell disease: association with hemolysis and inflammation. Blood. 2010;115(10): 2014-20. [PubMed: 20040765]

[228]. Duits AJ, Rodriguez T, Schnog JJ, Group CS. Serum levels of angiogenic factors indicate a proangiogenic state in adults with sickle cell disease. Br J Haematol. 2006;134(1):116-9. [PubMed: 16803577]

[229]. Mohan JS, Lip PL, Blann AD, Bareford D, Lip GY. The angiopoietin/Tie-2 system in proliferative sickle retinopathy: relation to vascular endothelial growth factor, its soluble receptor Flt-1 and von Willebrand factor, and to the effects of laser treatment. Br J Ophthalmol. 2005;89(7):815-9. [PubMed: 15965157]

[230]. Lopes FC, Traina F, Almeida CB, Leonardo FC, Franco-Penteado CF, Garrido VT, et al. Key endothelial cell angiogenic mechanisms are stimulated by the circulating milieu in sickle cell disease and attenuated by hydroxyurea. Haematologica. 2015;100(6):730-9. [PubMed: 25769545]

[231]. Michaels LA, Ohene-Frempong K, Zhao H, Douglas SD. Serum levels of substance P are elevated in patients with sickle cell disease and increase further during vaso-occlusive crisis. Blood. 1998;92(9):3148-51. [PubMed: 9787150]

[232]. Nur E, van Beers EJ, Martina S, Cuccovillo I, Otten HM, Schnog JJ, et al. Plasma levels of pentraxin-3, an acute phase protein, are increased during sickle cell painful crisis. Blood Cells Mol Dis. 2011;46(3):189-94. [PubMed: 21256776]

[233]. Elshazly SA, Heiba NM, Abdelmageed WM. Plasma PTX3 levels in sickle cell disease patients, during vaso occlusion and acute chest syndrome (data from Saudi population). Hematology. 2014;19(1):52-9. [PubMed: 23735470]

[234]. Gardner K, Thein SL. Genetic factors modifying sickle cell disease severity In: Costa FF, Conran N, editors. Sickle cell anemia: From basicsicence to cinical practice. Switzerland: Springer int; 2016 p. 371-98.

[235]. Joannes MO, Loko G, Deloumeaux J, Chout R, Marianne-Pepin T. Association of the +874 T/A interferon gamma polymorphism with infections in sickle cell disease. Int J Immunogenet. 2010;37(4):219-23. [PubMed: 20477883]

[236]. Belisario AR, Nogueira FL, Rodrigues RS, Toledo NE, Cattabriga AL, Velloso-Rodrigues C, et al. Association of alpha-thalassemia, TNF-alpha (-308G>A) and VCAM-1 (c.1238G>C) gene polymorphisms with cerebrovascular disease in a newborn cohort of 411 children with sickle cell anemia. Blood Cells Mol Dis. 2015;54(1):44-50. [PubMed: 25175566]

[237]. Hoppe C, Klitz W, D'Harlingue K, Cheng S, Grow M, Steiner L, et al. Confirmation of an association between the $\mathrm{TNF}(-308)$ promoter polymorphism and stroke risk in children with sickle cell anemia. Stroke. 2007;38(8):2241-6. [PubMed: 17600229]

[238]. Nolan VG, Adewoye A, Baldwin C, Wang L, Ma Q, Wyszynski DF, et al. Sickle cell leg ulcers: associations with haemolysis and SNPs in Klotho, TEK and genes of the TGF-beta/BMP pathway. Br J Haematol. 2006;133(5):570-8. [PubMed: 16681647]

[239]. Hu X, Jhun EH, Yao Y, He Y, Molokie RE, Wilkie DJ, et al. IL1A rs1800587 associates with chronic noncrisis pain in sickle cell disease. Pharmacogenomics. 2016;17(18):1999-2006. [PubMed: 27883292]

[240]. Kato GJ, Gladwin MT, Steinberg MH. Deconstructing sickle cell disease: reappraisal of the role of hemolysis in the development of clinical subphenotypes. Blood Rev. 2007;21(1):37-47. [PubMed: 17084951]

[241]. Potoka KP, Gladwin MT. Vasculopathy and pulmonary hypertension in sickle cell disease. Am J Physiol Lung Cell Mol Physiol. 2015;308(4):L314-24. [PubMed: 25398989] 
[242]. Wautier JL, Pintigny D, Maclouf J, Wautier MP, Corvazier E, Caen J. Release of prostacyclin after erythrocyte adhesion to cultured vascular endothelium. J Lab Clin Med. 1986;107(3):210-5. [PubMed: 3081670]

[243]. Mosseri M, Bartlett-Pandite AN, Wenc K, Isner JM, Weinstein R. Inhibition of endotheliumdependent vasorelaxation by sickle erythrocytes. Am Heart J. 1993;126(2):338-46. [PubMed: 8338004]

[244]. Brown MD, Wick TM, Eckman JR. Activation of vascular endothelial cell adhesion molecule expression by sickle blood cells. Pediatr Pathol Mol Med. 2001;20(1):47-72. [PubMed: 12673844]

[245]. Singla S, Sysol JR, Dille B, Jones N, Chen J, Machado RF. Hemin Causes Lung Microvascular Endothelial Barrier Dysfunction by Necroptotic Cell Death. Am J Respir Cell Mol Biol. 2017.

[246]. Conran N, Almeida CB, Lanaro C, Ferreira RP, Traina F, Saad ST, et al. Inhibition of caspasedependent spontaneous apoptosis via a cAMP-protein kinase A dependent pathway in neutrophils from sickle cell disease patients. Br J Haematol. 2007;139(1):148-58. [PubMed: 17711515]

[247]. Zachlederova M, Jarolim P. Gene expression in human lung microvascular cells interacting with sickle and calcium-loaded red cells and with inflammatory cytokines. Blood. 2000;96(11):598A+ .

[248]. Patel N, Sundaram N, Yang M, Madigan C, Kalra VK, Malik P. Placenta growth factor (PlGF), a novel inducer of plasminogen activator inhibitor-1 (PAI-1) in sickle cell disease (SCD). J Biol Chem. 2010;285(22):16713-22. [PubMed: 20351105]

[249]. Almeida CB, Souza LE, Leonardo FC, Costa FT, Werneck CC, Covas DT, et al. Acute hemolytic vascular inflammatory processes are prevented by nitric oxide replacement or a single dose of hydroxyurea. Blood. 2015.

[250]. Duits AJ, Pieters RC, Saleh AW, van Rosmalen E, Katerberg H, Berend K, et al. Enhanced levels of soluble VCAM-1 in sickle cell patients and their specific increment during vasoocclusive crisis. Clin Immunol Immunopathol. 1996;81(1):96-8. [PubMed: 8808648]

[251]. Embury SH, Matsui NM, Ramanujam S, Mayadas TN, Noguchi CT, Diwan BA, et al. The contribution of endothelial cell P-selectin to the microvascular flow of mouse sickle erythrocytes in vivo. Blood. 2004;104(10):3378-85. [PubMed: 15271798]

[252]. Gutsaeva DR, Parkerson JB, Yerigenahally SD, Kurz JC, Schaub RG, Ikuta T, et al. Inhibition of cell adhesion by anti-P-selectin aptamer: a new potential therapeutic agent for sickle cell disease. Blood. 2011;117(2):727-35. [PubMed: 20926770]

[253]. Kutlar A, Embury SH. Cellular adhesion and the endothelium: P-selectin. Hematol Oncol Clin North Am. 2014;28(2):323-39. [PubMed: 24589269]

[254]. Koehl B, Nivoit P, El Nemer W, Lenoir O, Hermand P, Pereira C, et al. The endothelin B receptor plays a crucial role in the adhesion of neutrophils to the endothelium in sickle cell disease. Haematologica. 2017;102(7):1161-72. [PubMed: 28385784]

[255]. Folkman J Angiogenesis in cancer, vascular, rheumatoid and other disease. Nat Med. 1995;1(1): 27-31. [PubMed: 7584949]

[256]. Naldini A, Carraro F. Role of inflammatory mediators in angiogenesis. Curr Drug Targets Inflamm Allergy. 2005;4(1):3-8. [PubMed: 15720228]

[257]. Chidlow JH, Jr., Shukla D, Grisham MB, Kevil CG. Pathogenic angiogenesis in IBD and experimental colitis: new ideas and therapeutic avenues. Am J Physiol Gastrointest Liver Physiol. 2007;293(1):G5-G18. [PubMed: 17463183]

[258]. Niland S, Eble JA. Integrin-mediated cell-matrix interaction in physiological and pathological blood vessel formation. J Oncol. 2012;2012:125278. [PubMed: 21941547]

[259]. Dobson SR, Holden KR, Nietert PJ, Cure JK, Laver JH, Disco D, et al. Moyamoya syndrome in childhood sickle cell disease: a predictive factor for recurrent cerebrovascular events. Blood. 2002;99(9):3144-50. [PubMed: 11964276]

[260]. Kim SY, Mocanu C, McLeod DS, Bhutto IA, Merges C, Eid M, et al. Expression of pigment epithelium-derived factor (PEDF) and vascular endothelial growth factor (VEGF) in sickle cell retina and choroid. Exp Eye Res. 2003;77(4):433-45. [PubMed: 12957143] 
[261]. Sundaram N, Tailor A, Mendelsohn L, Wansapura J, Wang X, Higashimoto T, et al. High levels of placenta growth factor in sickle cell disease promote pulmonary hypertension. Blood. 2010;116(1):109-12. [PubMed: 20335221]

[262]. Lee MT, Rosenzweig EB, Cairo MS. Pulmonary hypertension in sickle cell disease. Clin Adv Hematol Oncol. 2007;5(8):645-53. [PubMed: 17982405]

[263]. Shaikh S Intravitreal bevacizumab (Avastin) for the treatment of proliferative sickle retinopathy. Indian J Ophthalmol. 2008;56(3):259. [PubMed: 18417840]

[264]. Minniti CP, Eckman J, Sebastiani P, Steinberg MH, Ballas SK. Leg ulcers in sickle cell disease. Am J Hematol. 2010;85(10):831-3. [PubMed: 20872960]

[265]. Minniti CP, Taylor JGt, Hildesheim M, O’Neal P, Wilson J, Castro O, et al. Laboratory and echocardiography markers in sickle cell patients with leg ulcers. Am J Hematol. 2011;86(8):7058. [PubMed: 21630312]

[266]. Sapieha P, Hamel D, Shao Z, Rivera JC, Zaniolo K, Joyal JS, et al. Proliferative retinopathies: angiogenesis that blinds. Int J Biochem Cell Biol. 2010;42(1):5-12. [PubMed: 19836461]

[267]. Nagel RL, Fabry ME, Steinberg MH. The paradox of hemoglobin SC disease. Blood Rev. 2003;17(3):167-78. [PubMed: 12818227]

[268]. Costa FF, Fertrin KY. Clinical manifestations and treatment of adult sickle cell disease In: Costa FF, Conran N, editors. Sickle cell anemia: From basic science to clinical practice. 1 ed Switzerland: Springer International; 2016 p. 285-318.

[269]. Landburg PP, Nur E, Maria N, Brandjes DP, Biemond BJ, Schnog JB, et al. Elevated circulating stromal-derived factor-1 levels in sickle cell disease. Acta Haematol. 2009;122(1):64-9. [PubMed: 19816012]

[270]. Lopes FC, Ferreira R, Albuquerque DM, Silveira AA, Costa R, Soares R, et al. In vitro and in vivo anti-angiogenic effects of hydroxyurea. Microvasc Res. 2014;94:106-13. [PubMed: 24925859]

[271]. Platt OS, Thorington BD, Brambilla DJ, Milner PF, Rosse WF, Vichinsky E, et al. Pain in sickle cell disease. Rates and risk factors. N Engl J Med. 1991;325(1):11-6. [PubMed: 1710777]

[272]. Canalli AA, Proenca RF, Franco-Penteado CF, Traina F, Sakamoto TM, Saad ST, et al. Participation of Mac-1, LFA-1 and VLA-4 integrins in the in vitro adhesion of sickle cell disease neutrophils to endothelial layers, and reversal of adhesion by simvastatin. Haematologica. 2011;96(4):526-33. [PubMed: 21173096]

[273]. Hidalgo A, Chang J, Jang JE, Peired AJ, Chiang EY, Frenette PS. Heterotypic interactions enabled by polarized neutrophil microdomains mediate thromboinflammatory injury. Nat Med. 2009;15(4):384-91. [PubMed: 19305412]

[274]. Goldmann O, Medina E. The expanding world of extracellular traps: not only neutrophils but much more. Front Immunol. 2012;3:420. [PubMed: 23335924]

[275]. Pruchniak MP, Kotula I, Manda-Handzlik A. Neutrophil extracellular traps (Nets) impact upon autoimmune disorders. Cent Eur J Immunol. 2015;40(2):217-24. [PubMed: 26557037]

[276]. Yu Y, Su K. Neutrophil Extracellular Traps and Systemic Lupus Erythematosus. J Clin Cell Immunol. 2013;4.

[277]. Doring Y, Manthey HD, Drechsler M, Lievens D, Megens RT, Soehnlein O, et al. Autoantigenic protein-DNA complexes stimulate plasmacytoid dendritic cells to promote atherosclerosis. Circulation. 2012;125(13):1673-83. [PubMed: 22388324]

[278]. Schimmel M, Nur E, Biemond BJ, van Mierlo GJ, Solati S, Brandjes DP, et al. Nucleosomes and neutrophil activation in sickle cell disease painful crisis. Haematologica. 2013;98(11):1797803. [PubMed: 23911704]

[279]. Mathson K, Teena R, Belcher JD, Vercellotti GM, Slungaard A Thiocyanate Blocks PeroxidaseDependent Extracellular Trap (ET) Formation By PMN and Eosinophils: Heme Is a Potent New Agonist For The ET Pathway Blood 2013;122(21):323.

[280]. Belcher JD, Marker PH, Weber JP, Hebbel RP, Vercellotti GM. Activated monocytes in sickle cell disease: potential role in the activation of vascular endothelium and vaso-occlusion. Blood. 2000;96(7):2451-9. [PubMed: 11001897]

[281]. Sprague AH, Khalil RA. Inflammatory cytokines in vascular dysfunction and vascular disease. Biochem Pharmacol. 2009;78(6):539-52. [PubMed: 19413999] 
[282]. Brittain JE, Knoll CM, Ataga KI, Orringer EP, Parise LV. Fibronectin bridges monocytes and reticulocytes via integrin alpha4beta1. Br J Haematol. 2008;141(6):872-81. [PubMed: 18422998]

[283]. Wun T, Cordoba M, Rangaswami A, Cheung AW, Paglieroni T. Activated monocytes and platelet-monocyte aggregates in patients with sickle cell disease. Clin Lab Haematol. 2002;24(2): 81-8. [PubMed: 11985552]

[284]. Dutra FF, Alves LS, Rodrigues D, Fernandez PL, de Oliveira RB, Golenbock DT, et al. Hemolysis-induced lethality involves inflammasome activation by heme. Proc Natl Acad Sci U S A. 2014;111(39):E4110-8. [PubMed: 25225402]

[285]. Mendonca R, Silveira AA, Pericole FV, Seguin C, Leonardo FC, Saad STO, et al. Inflammasome-Dependent IL-1 beta Release from Neutrophils in Human Sickle Cell Anemia. Blood. 2016;128(22):854.

[286]. Brennan PJ, Brigl M, Brenner MB. Invariant natural killer T cells: an innate activation scheme linked to diverse effector functions. Nat Rev Immunol. 2013;13(2):101-17. [PubMed: 23334244]

[287]. Lin G, Field JJ, Yu JC, Ken R, Neuberg D, Nathan DG, et al. NF-kappaB is activated in CD4+ iNKT cells by sickle cell disease and mediates rapid induction of adenosine A2A receptors. PLoS One. 2013;8(10):e74664. [PubMed: 24124453]

[288]. Wallace KL, Linden J. Adenosine A2A receptors induced on iNKT and NK cells reduce pulmonary inflammation and injury in mice with sickle cell disease. Blood. 2010;116(23):5010 20. [PubMed: 20798237]

[289]. Kenny MW, George AJ, Stuart J. Platelet hyperactivity in sickle-cell disease: a consequence of hyposplenism. J Clin Pathol. 1980;33(7):622-5. [PubMed: 7430367]

[290]. Wun T, Paglieroni T, Rangaswami A, Franklin PH, Welborn J, Cheung A, et al. Platelet activation in patients with sickle cell disease. Br J Haematol. 1998;100(4):741-9. [PubMed: 9531343]

[291]. Proenca-Ferreira R, Franco-Penteado CF, Traina F, Saad ST, Costa FF, Conran N. Increased adhesive properties of platelets in sickle cell disease: roles for alphaIIb beta3-mediated ligand binding, diminished cAMP signalling and increased phosphodiesterase $3 \mathrm{~A}$ activity. $\mathrm{Br} \mathbf{J}$ Haematol. 2010;149(2):280-8. [PubMed: 20136824]

[292]. Triadou P, Fonty E, Ambrosio AS, Cottat MC, Girot R, Cornu P. Platelet function in sickle cell disease during steady state. Nouv Rev Fr Hematol. 1990;32(2):137-42. [PubMed: 2143013]

[293]. Mehta P, Mehta J. Abnormalities of platelet aggregation in sickle cell disease. J Pediatr. 1980;96(2):209-13. [PubMed: 7351581]

[294]. Villagra J, Shiva S, Hunter LA, Machado RF, Gladwin MT, Kato GJ. Platelet activation in patients with sickle disease, hemolysis-associated pulmonary hypertension, and nitric oxide scavenging by cell-free hemoglobin. Blood. 2007;110(6):2166-72. [PubMed: 17536019]

[295]. Browne PV, Mosher DF, Steinberg MH, Hebbel RP. Disturbance of plasma and platelet thrombospondin levels in sickle cell disease. Am J Hematol. 1996;51(4):296-301. [PubMed: 8602630]

[296]. Novelli EM, Kato GJ, Ragni MV, Zhang Y, Hildesheim ME, Nouraie M, et al. Plasma thrombospondin-1 is increased during acute sickle cell vaso-occlusive events and associated with acute chest syndrome, hydroxyurea therapy, and lower hemolytic rates. Am J Hematol. 2012;87(3):326-30. [PubMed: 22318901]

[297]. Tomer A, Harker LA, Kasey S, Eckman JR. Thrombogenesis in sickle cell disease. J Lab Clin Med. 2001;137(6):398-407. [PubMed: 11385360]

[298]. Tomer A Platelet activation as a marker for in vivo prothrombotic activity: detection by flow cytometry. J Biol Regul Homeost Agents. 2004;18(2):172-7. [PubMed: 15471223]

[299]. Serhan CN, Chiang N, Van Dyke TE. Resolving inflammation: dual anti-inflammatory and proresolution lipid mediators. Nat Rev Immunol. 2008;8(5):349-61. [PubMed: 18437155]

[300]. Walter MR. The molecular basis of IL-10 function: from receptor structure to the onset of signaling. Curr Top Microbiol Immunol. 2014;380:191-212. [PubMed: 25004819]

[301]. Hofmann SR, Rosen-Wolff A, Tsokos GC, Hedrich CM. Biological properties and regulation of IL-10 related cytokines and their contribution to autoimmune disease and tissue injury. Clin Immunol. 2012;143(2):116-27. [PubMed: 22459704] 
[302]. Sarray S, Saleh LR, Lisa Saldanha F, Al-Habboubi HH, Mahdi N, Almawi WY. Serum IL-6, IL-10, and TNFalpha levels in pediatric sickle cell disease patients during vasoocclusive crisis and steady state condition. Cytokine. 2015;72(1):43-7. [PubMed: 25569375]

[303]. Nath KA, Grande JP, Haggard JJ, Croatt AJ, Katusic ZS, Solovey A, et al. Oxidative stress and induction of heme oxygenase-1 in the kidney in sickle cell disease. Am J Pathol. 2001;158(3): 893-903. [PubMed: 11238038]

[304]. Belcher JD, Vineyard JV, Bruzzone CM, Chen C, Beckman JD, Nguyen J, et al. Heme oxygenase-1 gene delivery by Sleeping Beauty inhibits vascular stasis in a murine model of sickle cell disease. J Mol Med (Berl). 2010;88(7):665-75. [PubMed: 20306336]

[305]. Shi PA, Choi E, Chintagari NR, Nguyen J, Guo X, Yazdanbakhsh K, et al. Sustained treatment of sickle cell mice with haptoglobin increases HO-1 and H-ferritin expression and decreases iron deposition in the kidney without improvement in kidney function. Br J Haematol. 2016;175(4): 714-23. [PubMed: 27507623]

[306]. Beutler E The effect of carbon monoxide on red cell life span in sickle cell disease. Blood. 1975;46(2):253-9. [PubMed: 237591]

[307]. Keipert PE, Investigators MC-S-S. Clinical Evaluation of MP4CO: A Phase 1b Escalating-Dose, Safety and Tolerability Study in Stable Adult Patients with Sickle Cell Disease. Adv Exp Med Biol. 2016;923:23-9. [PubMed: 27526120]

[308]. Gomperts E, Belcher JD, Otterbein LE, Coates TD, Wood J, Skolnick BE, et al. The role of carbon monoxide and heme oxygenase in the prevention of sickle cell disease vaso-occlusive crises. Am J Hematol. 2017;92(6):569-82. [PubMed: 28378932]

[309]. Beckman JD, Belcher JD, Vineyard JV, Chen C, Nguyen J, Nwaneri MO, et al. Inhaled carbon monoxide reduces leukocytosis in a murine model of sickle cell disease. American Journal of Physiology: Heart \& Circulatory Physiology. 2009;297(4):H1243-53. [PubMed: 19617415]

[310]. Ahmed SM, Luo L, Namani A, Wang XJ, Tang X. Nrf2 signaling pathway: Pivotal roles in inflammation. Biochim Biophys Acta. 2017;1863(2):585-97.

[311]. Ghosh S, Ihunnah CA, Hazra R, Walker AL, Hansen JM, Archer DR, et al. Nonhematopoietic Nrf2 dominantly impedes adult progression of sickle cell anemia in mice. JCI Insight. 2016;1(4): e81090. [PubMed: 27158670]

[312]. Belcher JD, Chen C, Nguyen J, Zhang P, Abdulla F, Nguyen P, et al. Control of Oxidative Stress and Inflammation in Sickle Cell Disease with the Nrf2 Activator Dimethyl Fumarate. Antioxid Redox Signal. 2017;26(14):748-62. [PubMed: 26914345]

[313]. Pullarkat V, Meng Z, Tahara SM, Johnson CS, Kalra VK. Proteasome inhibition induces both antioxidant and $\mathrm{hb}$ f responses in sickle cell disease via the nrf2 pathway. Hemoglobin. 2014;38(3):188-95. [PubMed: 24670032]

[314]. Macari ER, Lowrey CH. Induction of human fetal hemoglobin via the NRF2 antioxidant response signaling pathway. Blood. 2011;117(22):5987-97. [PubMed: 21464371]

[315]. Krishnamoorthy S, Pace B, Gupta D, Sturtevant S, Li B, Makala L, et al. Dimethyl fumarate increases fetal hemoglobin, provides heme detoxification, and corrects anemia in sickle cell disease. JCI Insight. 2017;2(20):in press.

[316]. Cooper CE, Silaghi-Dumitrescu R, Rukengwa M, Alayash AI, Buehler PW. Peroxidase activity of hemoglobin towards ascorbate and urate: a synergistic protective strategy against toxicity of Hemoglobin-Based Oxygen Carriers (HBOC). Biochim Biophys Acta. 2008;1784(10):1415-20. [PubMed: 18457681]

[317]. Chintagari NR, Jana S, Alayash AI. Oxidized Ferric and Ferryl Forms of Hemoglobin Trigger Mitochondrial Dysfunction and Injury in Alveolar Type I Cells. American Journal of Respiratory Cell \& Molecular Biology. 2016;55(2):288-98. [PubMed: 26974230]

[318]. Bunn HF, Jandl JH. Exchange of heme among hemoglobins and between hemoglobin and albumin. J Biol Chem. 1968;243(3):465-75. [PubMed: 4966113]

[319]. Umbreit J Methemoglobin--it's not just blue: a concise review. Am J Hematol. 2007;82(2):13444. [PubMed: 16986127]

[320]. Ma B, Day JP, Phillips H, Slootsky B, Tolosano E, Dore S. Deletion of the hemopexin or heme oxygenase- 2 gene aggravates brain injury following stroma-free hemoglobin-induced intracerebral hemorrhage. J Neuroinflammation. 2016;13:26. [PubMed: 26831741] 
[321]. Hrkal Z, Vodrazka Z, Kalousek I. Transfer of heme from ferrihemoglobin and ferrihemoglobin isolated chains to hemopexin. Eur J Biochem. 1974;43(1):73-8. [PubMed: 4209590]

[322]. Barnard ML, Muller-Eberhard U, Turrens JF. Protective role of hemopexin on heme-dependent lung oxidative stress. Biochemical \& Biophysical Research Communications. 1993;192(1):82-7. [PubMed: 8476438]

[323]. Hunt RC, Hunt DM, Gaur N, Smith A. Hemopexin in the human retina: protection of the retina against heme-mediated toxicity. J Cell Physiol. 1996;168(1):71-80. [PubMed: 8647924]

[324]. Li RC, Saleem S, Zhen G, Cao W, Zhuang H, Lee J, et al. Heme-hemopexin complex attenuates neuronal cell death and stroke damage. Journal of Cerebral Blood Flow \& Metabolism. 2009;29(5):953-64. [PubMed: 19277051]

[325]. Tolosano E, Fagoonee S, Morello N, Vinchi F, Fiorito V. Heme scavenging and the other facets of hemopexin. Antioxid Redox Signal. 2010;12(2):305-20. [PubMed: 19650691]

[326]. Alayash AI. Haptoglobin: Old protein with new functions. Clin Chim Acta. 2011;412(7-8):4938. [PubMed: 21159311]

[327]. Baek JH, D’Agnillo F, Vallelian F, Pereira CP, Williams MC, Jia Y, et al. Hemoglobin-driven pathophysiology is an in vivo consequence of the red blood cell storage lesion that can be attenuated in guinea pigs by haptoglobin therapy. J Clin Invest. 2012;122(4):1444-58. [PubMed: 22446185]

[328]. Chen-Roetling J, Liu W, Regan RF. Hemopexin decreases hemin accumulation and catabolism by neural cells. Neurochem Int. 2012;60(5):488-94. [PubMed: 22342655]

[329]. Cooper CE, Schaer DJ, Buehler PW, Wilson MT, Reeder BJ, Silkstone G, et al. Haptoglobin binding stabilizes hemoglobin ferryl iron and the globin radical on tyrosine beta145. Antioxid Redox Signal. 2013;18(17):2264-73. [PubMed: 22702311]

[330]. Smith A, McCulloh RJ. Hemopexin and haptoglobin: allies against heme toxicity from hemoglobin not contenders. Front Physiol. 2015;6:187. [PubMed: 26175690]

[331]. Moestrup SK, Moller HJ. CD163: a regulated hemoglobin scavenger receptor with a role in the anti-inflammatory response. Ann Med. 2004;36(5):347-54. [PubMed: 15478309]

[332]. Nielsen MJ, Moller HJ, Moestrup SK. Hemoglobin and heme scavenger receptors. Antioxid Redox Signal. 2010;12(2):261-73. [PubMed: 19659436]

[333]. Smith A, Morgan WT. Haem transport to the liver by haemopexin. Receptor-mediated uptake with recycling of the protein. Biochem J. 1979;182(1):47-54. [PubMed: 496916]

[334]. Hvidberg V, Maniecki MB, Jacobsen C, Hojrup P, Moller HJ, Moestrup SK. Identification of the receptor scavenging hemopexin-heme complexes. Blood. 2005;106(7):2572-9. [PubMed: 15947085]

[335]. Philippidis P, Mason JC, Evans BJ, Nadra I, Taylor KM, Haskard DO, et al. Hemoglobin scavenger receptor CD163 mediates interleukin-10 release and heme oxygenase-1 synthesis: antiinflammatory monocyte-macrophage responses in vitro, in resolving skin blisters in vivo, and after cardiopulmonary bypass surgery. Circ Res. 2004;94(1):119-26. [PubMed: 14656926]

[336]. Ugocsai P, Barlage S, Dada A, Schmitz G. Regulation of surface CD163 expression and cellular effects of receptor mediated hemoglobin-haptoglobin uptake on human monocytes and macrophages. Cytometry A. 2006;69(3):203-5. [PubMed: 16479607]

[337]. Schaer CA, Vallelian F, Imhof A, Schoedon G, Schaer DJ. CD163-expressing monocytes constitute an endotoxin-sensitive $\mathrm{Hb}$ clearance compartment within the vascular system. $\mathrm{J}$ Leukoc Biol. 2007;82(1):106-10. [PubMed: 17460152]

[338]. Thomsen JH, Etzerodt A, Svendsen P, Moestrup SK. The haptoglobin-CD163-heme oxygenase-1 pathway for hemoglobin scavenging. Oxid Med Cell Longev. 2013;2013:523652. [PubMed: 23781295]

[339]. Schaer CA, Deuel JW, Schildknecht D, Mahmoudi L, Garcia-Rubio I, Owczarek C, et al. Haptoglobin Preserves Vascular Nitric Oxide Signaling during Hemolysis. Am J Respir Crit Care Med. 2016;193(10):1111-22. [PubMed: 26694989]

[340]. Hanson MS, Piknova B, Keszler A, Diers AR, Wang X, Gladwin MT, et al. Methaemalbumin formation in sickle cell disease: effect on oxidative protein modification and $\mathrm{HO}-1$ induction. $\mathrm{Br}$ J Haematol. 2011;154(4):502-11. [PubMed: 21595649] 
[341]. Fernandez I, Pena A, Del Teso N, Perez V, Rodriguez-Cuesta J. Clinical biochemistry parameters in C57BL/6J mice after blood collection from the submandibular vein and retroorbital plexus. J Am Assoc Lab Anim Sci. 2010;49(2):202-6. [PubMed: 20353696]

[342]. Kamal JK, Behere DV. Binding of heme to human serum albumin: steady-state fluorescence, circular dichroism and optical difference spectroscopic studies. Indian Journal of Biochemistry \& Biophysics. 2005;42(1):7-12. [PubMed: 23923575]

[343]. Vinchi F, De Franceschi L, Ghigo A, Townes T, Cimino J, Silengo L, et al. Hemopexin therapy improves cardiovascular function by preventing heme-induced endothelial toxicity in mouse models of hemolytic diseases. Circulation. 2013;127(12):1317-29. [PubMed: 23446829]

[344]. Santiago RP, Guarda CC, Figueiredo CVB, Fiuza LM, Adanho CSA, Aleluia MM, et al. Serum Haptoglobin and Hemopexin Levels in Pediatric SS and SC Disease Patients: Biomarker of Hemolysis and Inflammation. Blood. 2016;128(22):3649-.

[345]. Fagoonee S, Gburek J, Hirsch E, Marro S, Moestrup SK, Laurberg JM, et al. Plasma Protein Haptoglobin Modulates Renal Iron Loading. The American Journal of Pathology. 2005;166(4): 973-83. [PubMed: 15793279]

[346]. Vinchi F, Gastaldi S, Silengo L, Altruda F, Tolosano E. Hemopexin prevents endothelial damage and liver congestion in a mouse model of heme overload. Am J Pathol. 2008;173(1):289-99. [PubMed: 18556779]

[347]. Boretti FS, Buehler PW, D’Agnillo F, Kluge K, Glaus T, Butt OI, et al. Sequestration of extracellular hemoglobin within a haptoglobin complex decreases its hypertensive and oxidative effects in dogs and guinea pigs. J Clin Invest. 2009;119(8):2271-80. [PubMed: 19620788]

[348]. Lim SK, Kim H, bin Ali A, Lim YK, Wang Y, Chong SM, et al. Increased susceptibility in Hp knockout mice during acute hemolysis. Blood. 1998;92(6):1870-7. [PubMed: 9731043]

[349]. Tolosano E, Hirsch E, Patrucco E, Camaschella C, Navone R, Silengo L, et al. Defective recovery and severe renal damage after acute hemolysis in hemopexin-deficient mice. Blood. 1999;94(11):3906-14. [PubMed: 10572107]

[350]. Lim YK, Jenner A, Ali AB, Wang Y, Hsu SI, Chong SM, et al. Haptoglobin reduces renal oxidative DNA and tissue damage during phenylhydrazine-induced hemolysis. Kidney Int. 2000;58(3):1033-44. [PubMed: 10972668]

[351]. Tolosano E, Fagoonee S, Hirsch E, Berger FG, Baumann H, Silengo L, et al. Enhanced splenomegaly and severe liver inflammation in haptoglobin/hemopexin double-null mice after acute hemolysis. Blood. 2002;100(12):4201-8. [PubMed: 12393471]

[352]. Arredouani MS, Kasran A, Vanoirbeek JA, Berger FG, Baumann H, Ceuppens JL. Haptoglobin dampens endotoxin-induced inflammatory effects both in vitro and in vivo. Immunology. 2005;114(2):263-71. [PubMed: 15667571]

[353]. Chen L, Zhang X, Chen-Roetling J, Regan RF. Increased striatal injury and behavioral deficits after intracerebral hemorrhage in hemopexin knockout mice. J Neurosurg. 2011;114(4):1159-67. [PubMed: 21128737]

[354]. Buchanan GR, Glader BE. Leukocyte counts in children with sickle cell disease. Comparative values in the steady state, vaso-occlusive crisis, and bacterial infection. Am J Dis Child. 1978;132(4):396-8. [PubMed: 645659]

[355]. Lopez BL, Griswold SK, Navek A, Urbanski L. The complete blood count and reticulocyte count--are they necessary in the evaluation of acute vasoocclusive sickle-cell crisis? Acad Emerg Med. 1996;3(8):751-7. [PubMed: 8853669]

[356]. Rogovik AL, Li Y, Kirby MA, Friedman JN, Goldman RD. Admission and length of stay due to painful vasoocclusive crisis in children. Am J Emerg Med. 2009;27(7):797-801. [PubMed: 19683107]

[357]. Fadlon E, Vordermeier S, Pearson TC, Mire-Sluis AR, Dumonde DC, Phillips J, et al. Blood polymorphonuclear leukocytes from the majority of sickle cell patients in the crisis phase of the disease show enhanced adhesion to vascular endothelium and increased expression of CD64. Blood. 1998;91(1):266-74. [PubMed: 9414294]

[358]. Lachant NA, Oseas RS. Vaso-occlusive crisis-associated neutrophil dysfunction in patients with sickle-cell disease. Am J Med Sci. 1987;294(4):253-7. [PubMed: 3661621] 
[359]. Hierso R, Lemonne N, Villaescusa R, Lalanne-Mistrih ML, Charlot K, Etienne-Julan M, et al. Exacerbation of oxidative stress during sickle vaso-occlusive crisis is associated with decreased anti-band 3 autoantibodies rate and increased red blood cell-derived microparticle level: a prospective study. Br J Haematol. 2017;176(5):805-13. [PubMed: 27984639]

[360]. Duits AJ, Schnog JB, Lard LR, Saleh AW, Rojer RA. Elevated IL-8 levels during sickle cell crisis. Eur J Haematol. 1998;61(5):302-5. [PubMed: 9855244]

[361]. Setty BN, Stuart MJ. Eicosanoids in sickle cell disease: potential relevance of neutrophil leukotriene B4 to disease pathophysiology. J Lab Clin Med. 2002;139(2):80-9. [PubMed: 11919546]

[362]. Musa BO, Onyemelukwe GC, Hambolu JO, Mamman AI, Isa AH. Pattern of serum cytokine expression and T-cell subsets in sickle cell disease patients in vaso-occlusive crisis. Clin Vaccine Immunol. 2010;17(4):602-8. [PubMed: 20130127]

[363]. Garcia-Morin M, Lopez-Sanguos C, Vazquez P, Alvarez T, Maranon R, Huerta J, et al. Lactate Dehydrogenase: A Marker of the Severity of Vaso-Occlusive Crisis in Children with Sickle Cell Disease Presenting at the Emergency Department. Hemoglobin. 2016;40(6):388-91. [PubMed: 28361592]

[364]. Westerman M, Pizzey A, Hirschman J, Cerino M, Weil-Weiner Y, Ramotar P, et al. Microvesicles in haemoglobinopathies offer insights into mechanisms of hypercoagulability, haemolysis and the effects of therapy. Br J Haematol. 2008;142(1):126-35. [PubMed: 18422994]

[365]. Blander JM, Longman RS, Iliev ID, Sonnenberg GF, Artis D. Regulation of inflammation by microbiota interactions with the host. Nat Immunol. 2017;18(8):851-60. [PubMed: 28722709]

[366]. Hakansson A, Molin G. Gut microbiota and inflammation. Nutrients. 2011;3(6):637-82. [PubMed: 22254115]

[367]. Cario E, Brown D, McKee M, Lynch-Devaney K, Gerken G, Podolsky DK. Commensalassociated molecular patterns induce selective toll-like receptor-trafficking from apical membrane to cytoplasmic compartments in polarized intestinal epithelium. Am J Pathol. 2002;160(1):165-73. [PubMed: 11786410]

[368]. Testro AG, Visvanathan K. Toll-like receptors and their role in gastrointestinal disease. J Gastroenterol Hepatol. 2009;24(6):943-54. [PubMed: 19638078]

[369]. Deitch EA. The role of intestinal barrier failure and bacterial translocation in the development of systemic infection and multiple organ failure. Arch Surg. 1990;125(3):403-4. [PubMed: 2407230]

[370]. Tang WH, Kitai T, Hazen SL. Gut Microbiota in Cardiovascular Health and Disease. Circ Res. 2017;120(7):1183-96. [PubMed: 28360349]

[371]. Dror E, Dalmas E, Meier DT, Wueest S, Thevenet J, Thienel C, et al. Postprandial macrophagederived IL-1beta stimulates insulin, and both synergistically promote glucose disposal and inflammation. Nat Immunol. 2017;18(3):283-92. [PubMed: 28092375]

[372]. Wolowczuk I, Verwaerde C, Viltart O, Delanoye A, Delacre M, Pot B, et al. Feeding our immune system: impact on metabolism. Clin Dev Immunol. 2008;2008:639803. [PubMed: 18350123]

[373]. Keen CL, Gershwin ME. Zinc deficiency and immune function. Annu Rev Nutr. 1990;10:41531. [PubMed: 2200472]

[374]. Zhang D, Chen G, Manwani D, Mortha A, Xu C, Faith JJ, et al. Neutrophil ageing is regulated by the microbiome. Nature. 2015;525(7570):528-32. [PubMed: 26374999]

[375]. Sen CK. Oxidants and antioxidants in exercise. J Appl Physiol (1985). 1995;79(3):675-86. [PubMed: 8567503]

[376]. Barcelos RP, Bresciani G, Rodriguez-Miguelez P, Cuevas MJ, Soares FA, Barbosa NV, et al. Diclofenac pretreatment effects on the toll-like receptor 4/nuclear factor kappa B-mediated inflammatory response to eccentric exercise in rat liver. Life Sci. 2016;148:247-53. [PubMed: 26854180]

[377]. Bartzeliotou AI, Margeli AP, Tsironi M, Skenderi K, Bacoula C, Chrousos GP, et al. Circulating levels of adhesion molecules and markers of endothelial activation in acute inflammation induced by prolonged brisk exercise. Clin Biochem. 2007;40(11):765-70. [PubMed: 17320067] 
[378]. Toumi H, Best TM. The inflammatory response: friend or enemy for muscle injury? Br J Sports Med. 2003;37(4):284-6. [PubMed: 12893707]

[379]. Martin C, Pialoux V, Faes C, Charrin E, Skinner S, Connes P. Does physical activity increase or decrease the risk of sickle cell disease complications? Br J Sports Med. 2015; in press.

[380]. Chirico EN, Faes C, Connes P, Canet-Soulas E, Martin C, Pialoux V. Role of Exercise-Induced Oxidative Stress in Sickle Cell Trait and Disease. Sports Med. 2016;46(5):629-39. [PubMed: 26666745]

[381]. Kark JA, Posey DM, Schumacher HR, Ruehle CJ. Sickle-cell trait as a risk factor for sudden death in physical training. N Engl J Med. 1987;317(13):781-7. [PubMed: 3627196]

[382]. Harmon KG, Drezner JA, Klossner D, Asif IM. Sickle cell trait associated with a RR of death of 37 times in National Collegiate Athletic Association football athletes: a database with 2 million athlete-years as the denominator. Br J Sports Med. 2012;46(5):325-30. [PubMed: 22442191]

[383]. Connes P, Harmon KG, Bergeron MF. Pathophysiology of exertional death associated with sickle cell trait: can we make a parallel with vaso-occlusion mechanisms in sickle cell disease? Br J Sports Med. 2013;47(4):190. [PubMed: 22611148]

[384]. Connes P, Hue O, Tripette J, Hardy-Dessources MD. Blood rheology abnormalities and vascular cell adhesion mechanisms in sickle cell trait carriers during exercise. Clin Hemorheol Microcirc. 2008;39(1-4):179-84. [PubMed: 18503123]

[385]. Tripette J, Connes P, Hedreville M, Etienne-Julan M, Marlin L, Hue O, et al. Patterns of exercise-related inflammatory response in sickle cell trait carriers. Br J Sports Med. 2010;44(4): 232-7. [PubMed: 18499764]

[386]. Aufradet E, Monchanin G, Oyonno-Engelle S, Feasson L, Messonnier L, Francina A, et al. Habitual physical activity and endothelial activation in sickle cell trait carriers. Med Sci Sports Exerc. 2010;42(11):1987-94. [PubMed: 20386338]

[387]. Connes P, Machado R, Hue O, Reid H. Exercise limitation, exercise testing and exercise recommendations in sickle cell anemia. Clin Hemorheol Microcirc. 2011;49(1-4):151-63. [PubMed: 22214686]

[388]. Balayssac-Siransy E, Connes P, Tuo N, Danho C, Diaw M, Sanogo I, et al. Mild haemorheological changes induced by a moderate endurance exercise in patients with sickle cell anaemia. Br J Haematol. 2011;154(3):398-407. [PubMed: 21569006]

[389]. Liem RI, Onyejekwe K, Olszewski M, Nchekwube C, Zaldivar FP, Radom-Aizik S, et al. The acute phase inflammatory response to maximal exercise testing in children and young adults with sickle cell anaemia. Br J Haematol. 2015;171(5):854-61. [PubMed: 26456230]

[390]. Faes C, Balayssac-Siransy E, Connes P, Hivert L, Danho C, Bogui P, et al. Moderate endurance exercise in patients with sickle cell anaemia: effects on oxidative stress and endothelial activation. Br J Haematol. 2014;164(1):124-30. [PubMed: 24903630]

[391]. Faes C, Charrin E, Connes P, Pialoux V, Martin C. Chronic physical activity limits blood rheology alterations in transgenic SAD mice. Am J Hematol. 2015;90(2):E32-3. [PubMed: 25382738]

[392]. Charrin E, Dube JJ, Connes P, Pialoux V, Ghosh S, Faes C, et al. Moderate exercise training decreases inflammation in transgenic sickle cell mice. Blood Cells Mol Dis. 2017; in press.

[393]. Arnold SD, Bhatia M, Horan J, Krishnamurti L. Haematopoietic stem cell transplantation for sickle cell disease - current practice and new approaches. Br J Haematol. 2016;174(4):515-25. [PubMed: 27255787]

[394]. Niihara Y, Koh HA, Tran L, Razon RL, Macan H, Stark C, et al. A Phase 3 Study of L-Glutamine Therapy for Sickle Cell Anemia and Sickle B0-Thalassemia. Blood. 2014; 124(21): 86.

[395]. Niihara Y, Zerez CR, Akiyama DS, Tanaka KR. Oral L-glutamine therapy for sickle cell anemia: I. Subjective clinical improvement and favorable change in red cell NAD redox potential. Am J Hematol. 1998;58(2):117-21. [PubMed: 9625578]

[396]. Steinberg MH, Lu ZH, Barton FB, Terrin ML, Charache S, Dover GJ. Fetal hemoglobin in sickle cell anemia: determinants of response to hydroxyurea. Multicenter Study of Hydroxyurea. Blood. 1997;89(3):1078-88. [PubMed: 9028341] 
[397]. Charache S, Barton FB, Moore RD, Terrin ML, Steinberg MH, Dover GJ, et al. Hydroxyurea and sickle cell anemia. Clinical utility of a myelosuppressive "switching" agent. The Multicenter Study of Hydroxyurea in Sickle Cell Anemia. Medicine (Baltimore). 1996;75(6):300-26. [PubMed: 8982148]

[398]. Ware RE, Davis BR, Schultz WH, Brown RC, Aygun B, Sarnaik S, et al. Hydroxycarbamide versus chronic transfusion for maintenance of transcranial doppler flow velocities in children with sickle cell anaemia-TCD With Transfusions Changing to Hydroxyurea (TWiTCH): a multicentre, open-label, phase 3, non-inferiority trial. Lancet. 2016;387(10019):661-70. [PubMed: 26670617]

[399]. Bernaudin F, Verlhac S, Arnaud C, Kamdem A, Hau I, Leveille E, et al. Long-term treatment follow-up of children with sickle cell disease monitored with abnormal transcranial Doppler velocities. Blood. 2016;127(14):1814-22. [PubMed: 26851292]

[400]. Platt OS, Orkin SH, Dover G, Beardsley GP, Miller B, Nathan DG. Hydroxyurea enhances fetal hemoglobin production in sickle cell anemia. J Clin Invest. 1984;74(2):652-6. [PubMed: 6205021]

[401]. Chaar V, Laurance S, Lapoumeroulie C, Cochet S, De Grandis M, Colin Y, et al. Hydroxycarbamide decreases sickle reticulocyte adhesion to resting endothelium by inhibiting endothelial lutheran/basal cell adhesion molecule (Lu/BCAM) through phosphodiesterase 4A activation. J Biol Chem. 2014;289(16):11512-21. [PubMed: 24616094]

[402]. Bartolucci P, Chaar V, Picot J, Bachir D, Habibi A, Fauroux C, et al. Decreased sickle red blood cell adhesion to laminin by hydroxyurea is associated with inhibition of Lu/BCAM protein phosphorylation. Blood. 2010;116(12):2152-9. [PubMed: 20566895]

[403]. Cartron JP, Elion J. Erythroid adhesion molecules in sickle cell disease: effect of hydroxyurea. Transfus Clin Biol. 2008;15(1-2):39-50. [PubMed: 18515167]

[404]. Canalli AA, Franco-Penteado CF, Traina F, Saad ST, Costa FF, Conran N. Role for cAMPprotein kinase A signalling in augmented neutrophil adhesion and chemotaxis in sickle cell disease. Eur J Haematol. 2007;79(4):330-7. [PubMed: 17680813]

[405]. Gambero S, Canalli AA, Traina F, Albuquerque DM, Saad ST, Costa FF, et al. Therapy with hydroxyurea is associated with reduced adhesion molecule gene and protein expression in sickle red cells with a concomitant reduction in adhesive properties. Eur J Haematol. 2007;78(2):14451. [PubMed: 17313560]

[406]. Brun M, Bourdoulous S, Couraud PO, Elion J, Krishnamoorthy R, Lapoumeroulie C. Hydroxyurea downregulates endothelin-1 gene expression and upregulates ICAM-1 gene expression in cultured human endothelial cells. Pharmacogenomics J. 2003;3(4):215-26. [PubMed: 12931135]

[407]. Lapoumeroulie C, Benkerrou M, Odievre MH, Ducrocq R, Brun M, Elion J. Decreased plasma endothelin-1 levels in children with sickle cell disease treated with hydroxyurea. Haematologica. 2005;90(3):401-3. [PubMed: 15749673]

[408]. Colella MP, De Paula EV, Conran N, Machado-Neto JA, Annicchino-Bizzacchi JM, Costa FF, et al. Hydroxyurea is associated with reductions in hypercoagulability markers in sickle cell anemia. J Thromb Haemost. 2012;10(9):1967-70. [PubMed: 22817333]

[409]. King SB. The nitric oxide producing reactions of hydroxyurea. Curr Med Chem. 2003;10(6): 437-52. [PubMed: 12570692]

[410]. Almeida CB, Scheiermann C, Jang JE, Prophete C, Costa FF, Conran N, et al. Hydroxyurea and a cGMP-amplifying agent have immediate benefits on acute vaso-occlusive events in sickle cell disease mice. Blood. 2012;120(14):2879-88. [PubMed: 22833547]

[411]. Nottage K, Estepp J, Hankins JS. Future perspectives for the treatment of sickle cell anemia In: Costa FF, Conran N, editors. Sickle cell anemia: From basic science to clinical practice. Switzerland: Springer International; 2016 p. 399-429.

[412]. Cavazzana M, Antoniani C, Miccio A. Gene Therapy for beta-Hemoglobinopathies. Mol Ther. 2017;25(5):1142-54. [PubMed: 28377044]

[413]. Rai P, Malik P. Gene therapy for hemoglobin disorders - a mini-review. J Rare Dis Res Treat. 2016;1(2):25-31. [PubMed: 27891535] 
[414]. Kutlar A, Swerdlow PS, Meiler SE, Natrajan K, Wells LG, Clair B, et al. Pomalidomide In Sickle Cell Disease: Phase I Study Of a Novel Anti-Switching Agent. Blood. 2013;122(21).

[415]. dos Santos JL, Lanaro C, Lima LM, Gambero S, Franco-Penteado CF, Alexandre-Moreira MS, et al. Design, synthesis, and pharmacological evaluation of novel hybrid compounds to treat sickle cell disease symptoms. J Med Chem. 2011;54(16):5811-9. [PubMed: 21766854]

[416]. Fard AD, Hosseini SA, Shahjahani M, Salari F, Jaseb K. Evaluation of Novel Fetal Hemoglobin Inducer Drugs in Treatment of beta-Hemoglobinopathy Disorders. Int J Hematol Oncol Stem Cell Res. 2013;7(3):47-54. [PubMed: 24505535]

[417]. Zhang YK, Weiss M, Sumazin P, Sheehan VA. Metformin Induces FOXO3-Dependent Fetal Hemoglobin Production in Primary Erythroid Cells. Blood. 2016;128(22).

[418]. Li Q, Henry ER, Hofrichter J, Smith JF, Cellmer T, Dunkelberger EB, et al. Kinetic assay shows that increasing red cell volume could be a treatment for sickle cell disease. Proc Natl Acad Sci U S A. 2017;114(5):E689-E96. [PubMed: 28096387]

[419]. Wun T, Styles L, DeCastro L, Telen MJ, Kuypers F, Cheung A, et al. Phase 1 study of the Eselectin inhibitor GMI 1070 in patients with sickle cell anemia. PLoS One. 2014;9(7):e101301. [PubMed: 24988449]

[420]. Wun T, Telen MJ, Krishnamurti L, McCavit TL, DeCastro LM, Flanner H, et al. Pan-Selectin Antagonist Rivipansel (GMI-1070) Reduces Soluble E-Selectin Levels While Improving Clinical Outcomes in SCD Vaso-Occlusive Crisis Blood. 2014;124(21): 2704.

[421]. Telen MJ, Wun T, McCavit TL, De Castro LM, Krishnamurti L, Lanzkron S, et al. Randomized phase 2 study of GMI-1070 in SCD: reduction in time to resolution of vaso-occlusive events and decreased opioid use. Blood. 2015;125(17):2656-64. [PubMed: 25733584]

[422]. Manwani DM, Chen C, Carullo V, Cohen DW, Serban S, Olowukere O, et al. Vaso-OcclusionPromoting Neutrophil Mac-1 Integrin Activation in Human Sickle Cell Crises Is Stabilized By a Single Dose of Intravenous Gammaglobulin Blood. 2014;124(21): 4089.

[423]. Cheung ATW, Chan MS, Ramanujam S, Rangaswami A, Curl K, Franklin P, et al. Effects of poloxamer 188 treatment on sickle cell vaso-occlusive crisis: Computer-assisted intravital microscopy study. Journal of Investigative Medicine. 2004;52(6):402-6. [PubMed: 15612454]

[424]. Okpala I Investigational selectin-targeted therapy of sickle cell disease. Expert Opin Investig Drugs. 2015;24(2):229-38.

[425]. Ataga KI, Kutlar A, Kanter J, Liles D, Cancado R, Friedrisch J, et al. Crizanlizumab for the Prevention of Pain Crises in Sickle Cell Disease. N Engl J Med. 2017;376(5):429-39. [PubMed: 27959701]

[426]. Heeney MM, Hoppe CC, Abboud MR, Inusa B, Kanter J, Ogutu B, et al. A Multinational Trial of Prasugrel for Sickle Cell Vaso-Occlusive Events. N Engl J Med. 2016;374(7):625-35. [PubMed: 26644172]

[427]. Hoppe C, Kuypers F, Larkin S, Hagar W, Vichinsky E, Styles L. A pilot study of the short-term use of simvastatin in sickle cell disease: effects on markers of vascular dysfunction. $\mathrm{Br} \mathbf{J}$ Haematol. 2011;153(5):655-63. [PubMed: 21477202]

[428]. Field JJ, Ataga KI, Majerus EM, Eaton CA, Mashal R, Nathan DG. A Phase I Single Ascending Dose Study Of NKTT120 In Stable Adult Sickle Cell Patients. Blood. 2013;122(21):977.

[429]. Belcher JD, Chen CS, Nguyen J, Abdulla F, Nguyen P, Nguyen H, et al. Haptoglobin and Hemopexin Infusion Efficiently Activates the Nrf2/HO-1 Axis and Inhibits Inflammation and Vaso-Occlusion in Murine Sickle Cell Disease. Blood. 2016;128(22).

[430]. Owusu-Ansah A, Choi SH, Petrosiute A, Letterio JJ, Huang AY. Triterpenoid inducers of Nrf2 signaling as potential therapeutic agents in sickle cell disease: a review. Front Med. 2015;9(1): 46-56. [PubMed: 25511620]

[431]. Misra H, Bainbridge J, Berryman J, Abuchowski A, Galvez KM, Uribe LF, et al. A Phase Ib open label, randomized, safety study of SANGUINATE in patients with sickle cell anemia. Rev Bras Hematol Hemoter. 2017;39(1):20-7. [PubMed: 28270341]

[432]. Howard J, Thein SL, Galacteros F, Inati A, Reid M, Keipert PE, et al. Safety and Tolerability Of MP4CO: A Dose Escalation Study In Stable Patients With Sickle Cell Disease. Blood. 2013;122(21):2205. [PubMed: 23945154] 
[433]. Almeida CB, Traina F, Lanaro C, Canalli AA, Saad ST, Costa FF, et al. High expression of the cGMP-specific phosphodiesterase, PDE9A, in sickle cell disease (SCD) and the effects of its inhibition in erythroid cells and SCD neutrophils. Br J Haematol. 2008;142(5):836-44. [PubMed: 18564357]

[434]. Schmidt HH, Schmidt PM, Stasch JP. NO- and haem-independent soluble guanylate cyclase activators. Handb Exp Pharmacol. 2009(191):309-39.

[435]. Risbano MG, Gladwin MT. Therapeutics targeting of dysregulated redox equilibrium and endothelial dysfunction. Handb Exp Pharmacol. 2013;218:315-49. [PubMed: 24092346]

[436]. Venereau E, Ceriotti C, Bianchi ME. DAMPs from Cell Death to New Life. Front Immunol. 2015;6:422. [PubMed: 26347745]

[437]. Almeida CB, Kato GJ, Conran N. Inflammation and sickle cell anemia In: Costa FF, Conran N, editors. Sickle cell anemia: From basic science to clinical practice. New York: Springer 2016 p. 177-211.

[438]. Silveira AA, Cunningham C, Corr E, Ferreira WA, Jr., Costa FF, Almeida CB, et al. Heme Induces NLRP3 Inflammasome Formation in Primary Human Macrophages and May Propagate Hemolytic Inflammatory Processes By Inducing S100A8 Expression. Blood. 2016;128::1256.

[439]. Hanson MS, Xu H, Flewelen TC, Holzhauer SL, Retherford D, Jones DW, et al. A novel hemoglobin-binding peptide reduces cell-free hemoglobin in murine hemolytic anemia. Am J Physiol Heart Circ Physiol. 2013;304(2):H328-36. [PubMed: 23125208]

[440]. Hoppe C, Jacob E, Styles L, Kuypers F, Larkin S, Vichinsky E. Simvastatin reduces vasoocclusive pain in sickle cell anaemia: a pilot efficacy trial. Br J Haematol. 2017;177(4):620-9. [PubMed: 28369718]

[441]. Solovey A, Somani A, Chen CS, Kiley J, Marker P, Abdulla F, et al. Interference With TNF alpha Using Long-Term Etanercept In S+S-Antilles Sickle Transgenic Mice Ameliorates Abnormal Endothelial Activation, Vasoocclusion, and Pulmonary Hypertension Including Its Pulmonary Arterial Wall Remodeling. Blood. 2013;122(21):728.

[442]. Kaul DK, Thangaswamy S, Suzuka SM, Fabry ME, Wanderer AA, Gram H. Anti-Interleukin-1 $\beta$ Antibody-Based Therapy Ameliorates Endothelial Activation and Inflammation in Sickle Mice. Blood. 2011;118(21):848.

[443]. Field JJ, Majerus E, Ataga KI, Vichinsky EP, Schaub R, Mashal R, et al. NNKTT120, an antiiNKT cell monoclonal antibody, produces rapid and sustained iNKT cell depletion in adults with sickle cell disease. PLoS One. 2017;12(2):e0171067. [PubMed: 28152086]

[444]. Telen MJ, Batchvarova M, Shan S, Bovee-Geurts PH, Zennadi R, Leitgeb A, et al. Sevuparin binds to multiple adhesive ligands and reduces sickle red blood cell-induced vaso-occlusion. $\mathrm{Br} \mathrm{J}$ Haematol. 2016;175(5):935-48. [PubMed: 27549988]

[445]. Sandor B, Marin M, Lapoumeroulie C, Rabai M, Lefevre SD, Lemonne N, et al. Effects of Poloxamer 188 on red blood cell membrane properties in sickle cell anaemia. Br J Haematol. 2016;173(1):145-9. [PubMed: 26846309]

[446]. Wun T, Soulieres D, Frelinger AL, Krishnamurti L, Novelli EM, Kutlar A, et al. A double-blind, randomized, multicenter phase 2 study of prasugrel versus placebo in adult patients with sickle cell disease. J Hematol Oncol. 2013;6:17. [PubMed: 23414938]

[447]. Desai PC, Brittain JE, Jones SK, McDonald A, Wilson DR, Dominik R, et al. A pilot study of eptifibatide for treatment of acute pain episodes in sickle cell disease. Thrombosis Research. 2013;132(3):341-5. [PubMed: 23973010]

[448]. Morris CR, Kuypers FA, Lavrisha L, Ansari M, Sweeters N, Stewart M, et al. A randomized, placebo-controlled trial of arginine therapy for the treatment of children with sickle cell disease hospitalized with vaso-occlusive pain episodes. Haematologica. 2013;98(9):1375-82. [PubMed: 23645695]

[449]. Wajih N, Basu S, Jailwala A, Kim HW, Ostrowski D, Perlegas A, et al. Potential therapeutic action of nitrite in sickle cell disease. Redox Biol. 2017;12:1026-39. [PubMed: 28511346]

[450]. Minniti CP, Gorbach AM, Xu D, Hon YY, Delaney KM, Seidel M, et al. Topical sodium nitrite for chronic leg ulcers in patients with sickle cell anaemia: a phase 1 dose-finding safety and tolerability trial. Lancet Haematol. 2014;1(3):e95-e103. [PubMed: 25938131] 
[451]. Stasch JP, Evgenov OV. Soluble guanylate cyclase stimulators in pulmonary hypertension. Handb Exp Pharmacol. 2013;218:279-313. [PubMed: 24092345]

[452]. Miguel LI, Almeida CB, Traina F, Canalli AA, Dominical VM, Saad STO, et al. Inhibition of phosphodiesterase 9A reduces cytokine-stimulated in vitro adhesion of neutrophils from sickle cell anemia individuals. Inflammation Res. 2011;60(7):633-42.

[453]. Ikuta T, Ausenda S, Cappellini MD. Mechanism for fetal globin gene expression: role of the soluble guanylate cyclase-cGMP-dependent protein kinase pathway. Proc Natl Acad Sci U S A. 2001;98(4):1847-52. [PubMed: 11172039]

[454]. McArthur JG, Maciel T, Chen C, Fricot A, Kobayashi D, Nguyen J, Nguyen P, Parachova A, Abdulla F, Vercellotti GM, Svenstrup N, \& Belcher JD A Novel, Highly Potent and Selective PDE9 Inhibitor for the Treatment of Sickle Cell Disease. Blood. 2016;128(22):268.

[455]. Ataga KI, Reid M, Ballas SK, Yasin Z, Bigelow C, St James L, et al. Improvements in haemolysis and indicators of erythrocyte survival do not correlate with acute vaso-occlusive crises in patients with sickle cell disease: a phase III randomized, placebo-controlled, doubleblind study of the gardos channel blocker senicapoc (ICA-17043). Br J Haematol. 2011;153(1): 92-104. [PubMed: 21323872]

[456]. Conran N Prospects for early investigational therapies for sickle cell disease. Expert Opin Investig Drugs. 2015;24(5):595-602. 


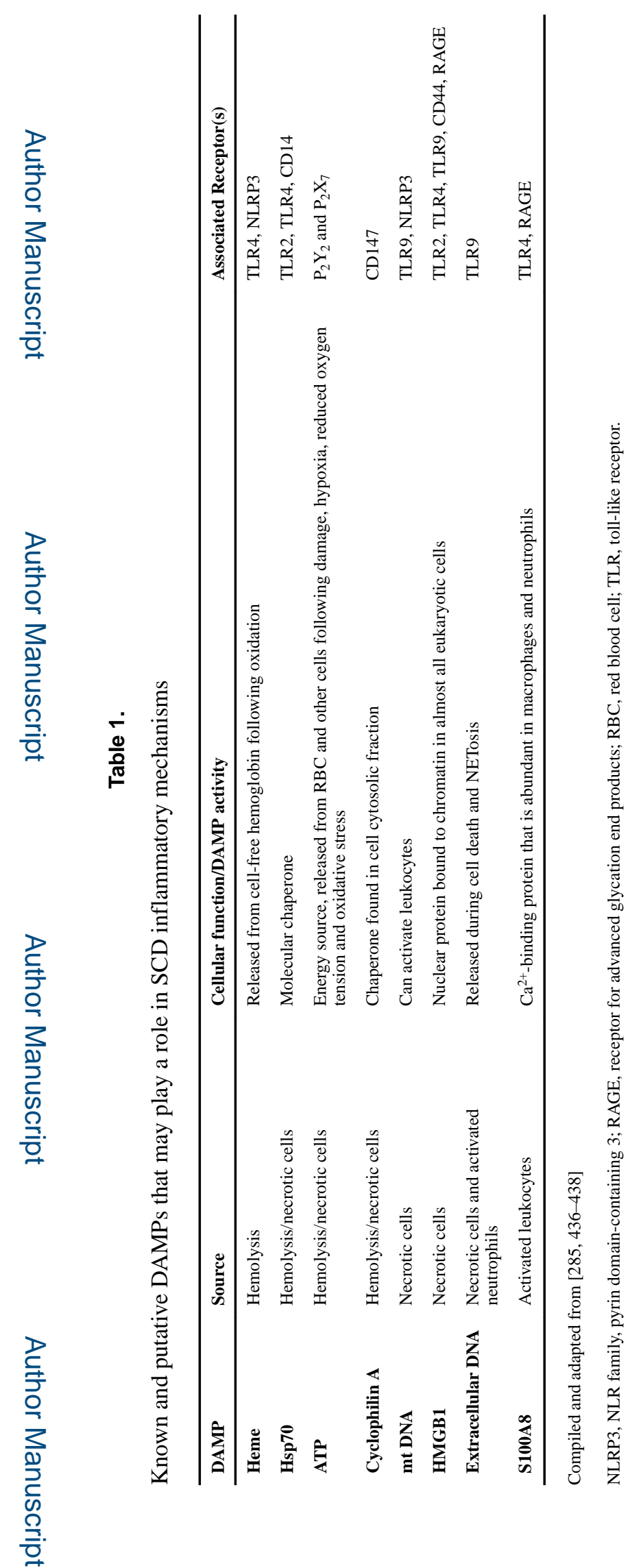

Clin Hemorheol Microcirc. Author manuscript; available in PMC 2019 January 02. 


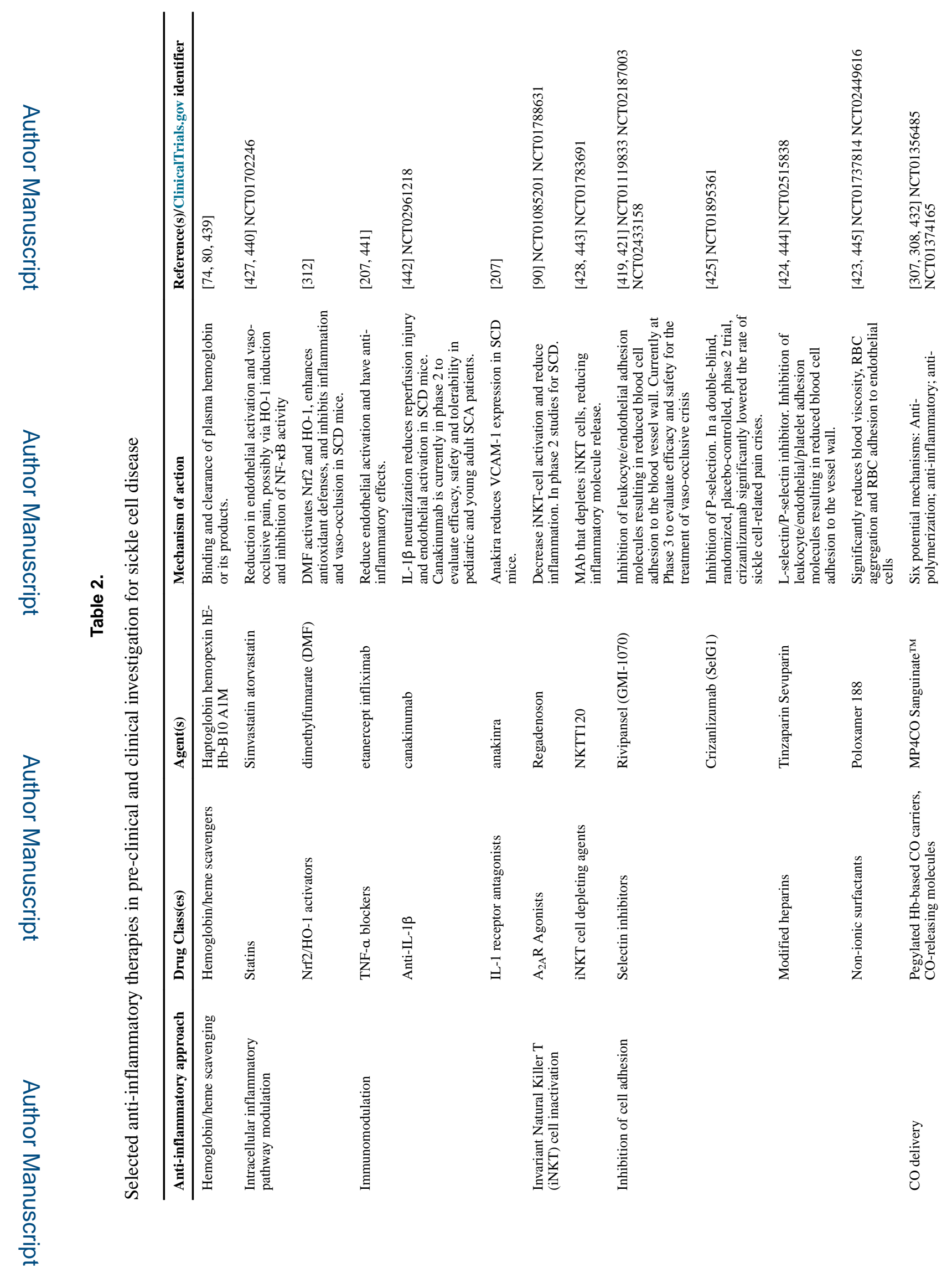

Clin Hemorheol Microcirc. Author manuscript; available in PMC 2019 January 02. 


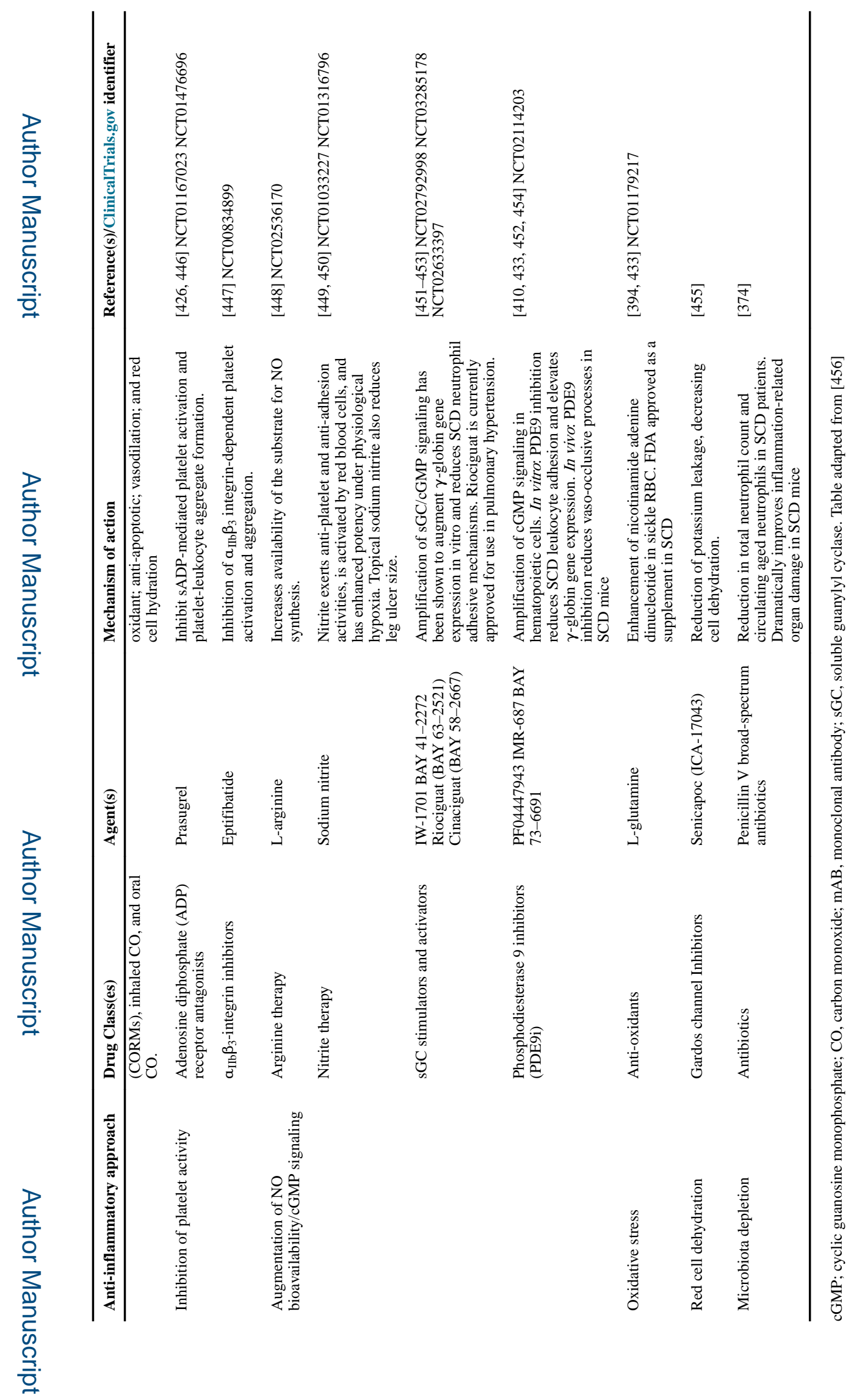

Clin Hemorheol Microcirc. Author manuscript; available in PMC 2019 January 02. 